\title{
The Šariš Transitional Zone, revealing interactions between Pieniny Klippen Belt, Outer Carpathians and European platform
}

\author{
Edyta Jurewicz ${ }^{1}$
}

Received: 4 January 2017 / Accepted: 21 December 2017 / Published online: 16 January 2018

(C) The Author(s) 2018. This article is an open access publication

\begin{abstract}
The Pieniny Klippen Belt (PKB) is a narrow structure delineating the boundary between the Central and Outer Carpathians. It is built of nappes stacked during the Cretaceous and Paleocene and then re-folded in the Miocene during the formation of the Outer Carpathian overthrusts. The internal structure of the PKB at the Polish/Slovakian border first formed during northward nappe thrusting processes, which were most intense at the turn of the Cretaceous to the Paleocene. A secondary factor is the change in strike of the PKB turning from W-E to WNW-ESE, associated with dextral strike-slip faulting in the Carpathian basement (North-European Platform). These NNW-SSE oriented strike-slip fault zones, broadly parallel to the Teisseyre-Tornquist Zone, are responsible for the segmentation of the down-going plate, which influenced the subduction and collision between the North-European Platform and the Central Carpathian Block. Among them, the most important role was played by the Kraków-Myszków Fault Zone separating the Małopolska and Upper Silesian blocks in the Carpathian foreland. Shifts and interactions between the neighboring Pieniny and Outer Carpathian basins-during contemporaneous sedimentation and deformation-resulted in a difficult-to-define, transitional zone. Until now this zone had the rank of a tectonic unit, named "Grajcarek Unit" in Poland and "Šariš Unit" in the Slovak Republic. However, its northern boundary, often taken to represent the Central/Outer Carpathians boundary, is ambiguous. These problems are due to the spatial overlap of thrusting and gravitational flows resulting in chaotic breccias, olistoliths and olistostrome formation, which formed repeatedly and became deformed during the Maastrichtian to Early Miocene. Tectonic deformations in this area gradually vanished towards the north. This zone can therefore be defined as the Peri-Klippen part of the Magura Nappe that lacks a distinct northern tectonic limit. For this reason it is named Šariš Transitional Zone ( ̌̌TZ).
\end{abstract}

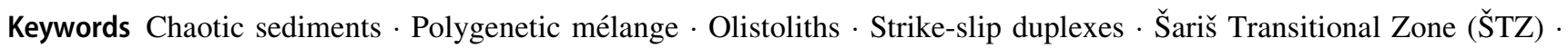
Pieniny Klippen Belt (PKB)

\section{Introduction}

Chaotic sedimentary deposits typically appear in the foreland of thrust-belts and accretionary prisms and are synchronous with nappe thrusting processes. Their genesis may involve gravity-induced sedimentary processes such

Editorial handling: S. Schmid.

Electronic supplementary material The online version of this article (https://doi.org/10.1007/s00015-017-0297-9) contains supplementary material, which is available to authorized users.

Edyta Jurewicz

edyta.jurewicz@uw.edu.pl

1 Faculty of Geology, University of Warsaw, Al. Żwirki i Wigury 93, 02-089 Warsaw, Poland as slumping and olistostrome formation (Festa et al. 2016) and/or purely tectonic disintegration (mélange formation; Hsü 1968). Usually they are composed of a shaly matrix with blocks of both local and exotic material.

In the literature the most external part of the Pieniny Klippen Belt, near the Poland-Slovakia border, is referred to as Grajcarek Unit in Poland (Birkenmajer 1977, 1986) or Šariš (Fakl'ovka) Unit in the Slovak Republic (Plašienka et al. 2012). It has the character of a transitional zone towards the Outer Carpathians. This unit formed as an effect of interactions between the Pieniny Klippen Belt and the northerly adjacent the Magura basins as a part of the Outer Carpathians that define the Carpathians arc (Fig. 1a, b), which formed during the Paleogene-Neogene as the result of subduction and convergence of Alcapa with the European plate (e.g. Nemčok et al. 1998 ; Froitzheim et al. 


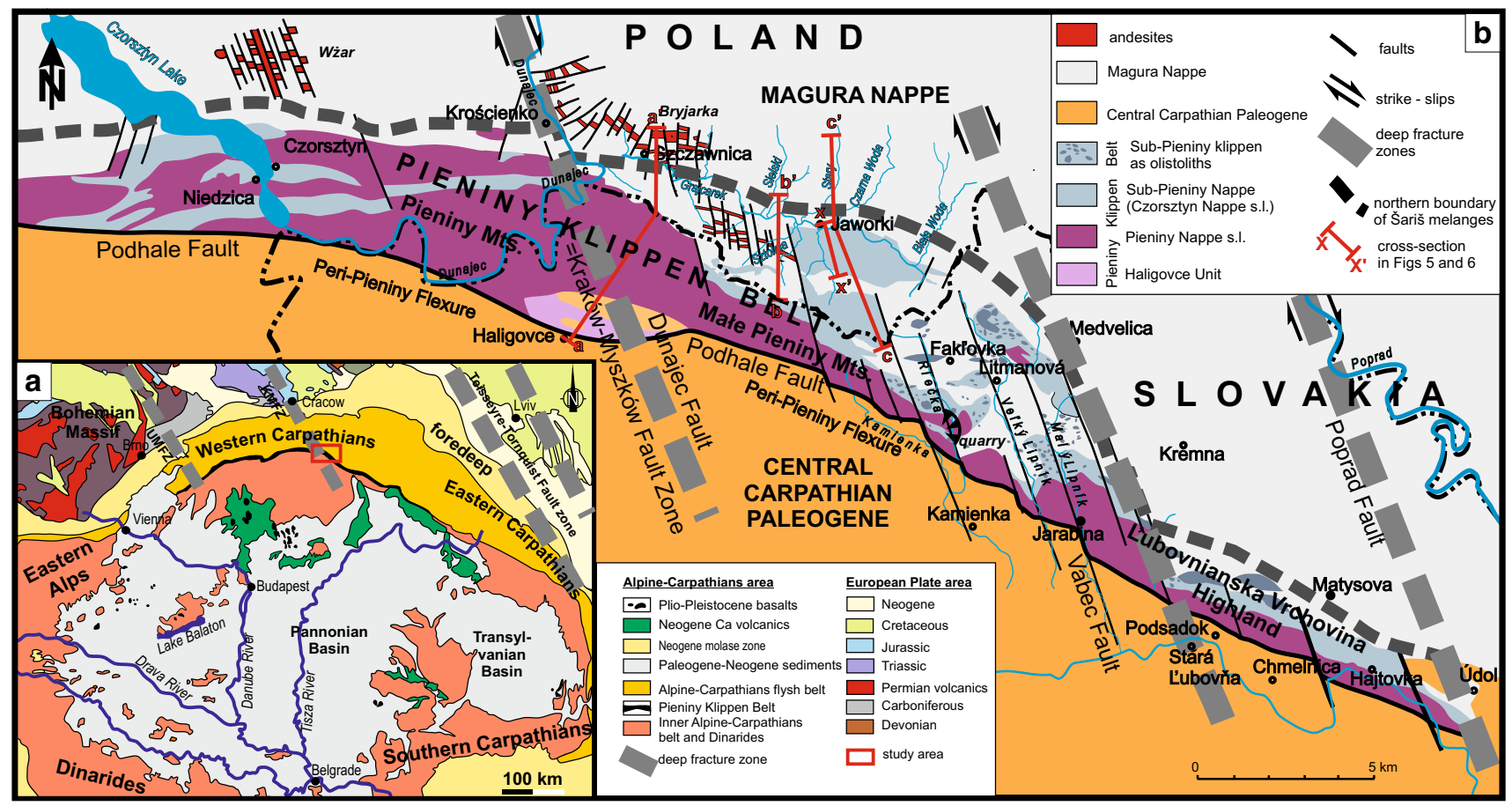

Fig. 1 a Main tectonic units of the Alpine-Carpathian-Pannonian orogenic belt and the location of the study area; after Embey-Isztin et al. (1993) and Kováč and Márton (1998), simplified by Jurewicz (2005). b Geological sketch-map of the Małe Pieniny Mts. and the

2008). This impact can be observed both in terms of stages during sedimentation and deformation.

The Grajcarek Unit was first defined by Birkenmajer (1970, 1977, 1986) as a Peri-Klippen part of the Magura Basin deposits, which was back thrusted over the nappes of the Klippen Belt thereby becoming part of the PKB, forming tectonic caps. These caps formed during the Maastrichtian-Paleocene ("Laramian") phase after integration of the PKB into the accretionary prism. In contrast, Jurewicz $(1994,1997)$ postulated that during the last phase of nappe thrusting affecting the PKB the klippen units moved northward over the Magura foreland forming mostly gravitationally driven folds and thrusts. As a consequence the "Grajcarek Unit", now crops out in tectonic windows. This unit, transitional in character, consists of strongly deformed slices composed of Jurassic-Cretaceous sediments associated with synorogenic wild-flysch, breccia type sediments and numerous olistoliths. According to Plašienka (2012a), a unit he called Šariš Unit forms the lowermost unit of the PKB. It formed due to repeated gravity slides continuing episodically until to the Early Eocene. The question became more confusing after Oszczypko and Oszczypko-Clowes $(2010,2014)$ documented Miocene sediments (Kremna Formation) inside the PKB. On the basis of this observation they proposed that the nappes of the PKB were thrust together with what he called Grajcarek Unit along a flat-lying thrust onto the Miocene of
Lubovnianska Vrchovina Highland, based on Birkenmajer (1979), Jurewicz (1994), Plašienka (2012), but simplified and modified. Traces of sections presented in Fig. 4 and Online Resource 3 are indicated

the Magura Nappe. If correct, the idea of the PKB up to date conceived as a semi-vertical and deep-rooted structure, would cease to exist. One of the aims of this paper is to re-examine these different models and to propose a new model for the evolution of the Klippen Belt whereby the Grajcarek Unit is taken as a part of the Šariš Transitional Zone representing a transitional zone between the PKB and the Other Carpathians. In the following the name "Grajcarek" will be reserved to the lithostratigraphic succession of the Grajcarek Basin (Birkenmajer and Gedl 2017), which existed during Jurassic and Early Cretaceous times as the most southern (Peri-Klippen) part of the Magura Basin.

Moving from west to east along the Polish/Slovakian border, i.e. from the Pieniny Mts. through the Małe Pieniny Mts. to the Lubovnianska Vrchovina Highland (Fig. 1b), there is a gradual change in both the PKB structure and its relation to the Magura Nappe. One reason for this change could be caused by the influence of structures present in the Carpathian basement, i.e. the North-European Platform below the Outer Carpathians. During the last stage of the Carpathian orogeny this plate was forced below the nascent orogen, undercutting and underplating the PKB. However, thereby the platform did not behave like a monolithic rigid block but was cut by a number of faults. These faults, deeprooted fracture zones, played a key role for the lateral variations of deformation style and, consequently, the 
geological structure of the PKB. These faults are generally parallel to the Teisseyre-Tornquist Zone (e.g. Pożaryski 1991; Pharaoh 1999; Świdrowska and Hakenberg 2000; Dadlez 2006; Guterch and Grad 2006, Gawęda et al. 2017), oriented NNW-SSE. One of the aims is to show the reasons for the complexity of the structure of the PKB, stemming from the character and the dynamics of the collision of the North-European Platform with the Central Carpathians Block, that is a part of the Alcapa Megaunit.

\section{Geological setting}

The Pieniny Klippen Belt (PKB) is up to $600 \mathrm{~km}$ long, only a few $\mathrm{km}$ wide, and follows the boundary between the Outer and the Central Carpathians (Fig. 1a). The PKB was represented an accretionary prism during the southward subduction of the European plate (e.g. Royden 1993; Zoetemeijer et al. 1999; Csontos and Vörös 2004; Froitzheim et al. 2008; Hrubcová and Środa 2015). In a structural and genetic sense it is a particular tectonic unit linking two nappe-systems: the Paleoalpine Central Carpathians and the Neoalpine Flysch Belt (Mahel' 1980, 1989). Kozur and Mock (1996) considered the Pieniny Basin to be a northern branch of the (southern) Penninic Ocean in the Western Alps, existing already in the Early Triassic. The oblique rift probably had a WSW-ENE or SW-NE trend (Marchant and Stampfli 1997; Stampfli et al. 1998; Dumont et al. 1996; Jurewicz 2005). Plašienka (1999) divided the Penninic Basin into the Vahicum (Vahic) and Magura subbasins, separated by the Oravicum (Oravic, Czorsztyn Ridge). The Czorsztyn Ridge is correlated with the Briançonnais by i.e. Trümpy (1988), Tomek (1993) and Stampfli (1993), and the Magura Basin is linked with the Valaisan by Schmid et al. (2008).

The PKP is composed of nappe units resulting from multiple folding processes in the Late Cretaceous and Paleogene and its overstepping Cenozoic sedimentary cover (Birkenmajer 1986; Plašienka et al. 2012). Birkenmajer $(1977,1979,1986)$ distinguished three main sedimentary zones within the originally at least $120-150 \mathrm{~km}$ wide PKB basin. These zones are: (a) a northern (Czorsztyn s.l.) ridge; (b) a central trough (Pieniny s.l.) and (c) a southern ridge called Andrusov Ridge). Within the study area, these three zones correspond, respectively, to the following klippen successions/structural units:

Zone A: Czorsztyn lithostratigraphic unit s.l. (Sub-Pieniny after Uhlig 1907; Sikora 1971; Książkiewicz 1977; Plašienka et al. 2012), subdivided in the Polish part into the Czorsztyn unit s.s. and the Czertezik and Niedzica subunits (Jarabina and Mašlienka subunits in the Slovak sector of the study area; Plašienka et al. 2012);
Zone B: Pieniny lithostratigraphic unit s.l., subdivided into Branisko/Kysuca subunit and Pieniny unit s.s.

Zone C: Haligovce lithostratigraphic unit (correlated with the Central Carpathians Austroalpine provenance, incorporated into the PKB; Plašienka 2011).

In addition to the lithostratigraphic units listed above, another special unit has been described in the literature, extending along the northern boundary of the PKB and separating it from the Outer Carpathians further north. This unit that is transitional in terms of sedimentation and tectonic evolution is the previously mentioned Grajcarek Unit of Poland (Birkenmajer 1977, 1986; Birkenmajer and Gedl 2017; Oszczypko and Oszczypko-Clowes 2014), called Šariš or Fakl'ovka Unit in the Slovak Republic (Plašienka and Mikuš 2010; Plašienka et al. 2012).

A later important event during the evolution of the PKB, documented e.g. in the Małe Pieniny Mts. by the Lower Eocene conglomerates (Birkenmajer and Pazdro 1968), led to sedimentation connected with the burial and formation of the Central Carpathian Paleogene Basin (CCPB) (e.g. Marschalko 1968). According to Soták et al. (2001), the CCPB formed as a marginal sea of the Peri-Tethyan Basin, which shows a fore-arc position developed in the Outer Carpathians accretionary prism. During this stage of its evolution the PKB obtained a sedimentary cover composed of Lower Eocene-Oligocene flysch deposits (e.g. Andrusov 1938; Bieda 1959, 1963; Alexandrowicz and Geroch 1963; Birkenmajer 1970; Olszewska and Wieczorek 1998; Gross et al. 1984; Gedl 1999, 2000).

During the Oligocene and Early Miocene, the oblique collision of the Alcapa microplate with the North European Platform took place (Nemcok et al. 1998), leading to the development of the Outer Carpathian accretionary wedge, built up of many flysch nappes and the formation of a Carpathian foredeep (e.g. Nemcok et al. 1998; Oszczypko 1998; Golonka et al. 2000; Oszczypko and OszczypkoClowes 2003). The last stage of nappe formation in the Polish part of the Western Carpathians occurred in Badenian-Sarmatian times (Oszczypko 1998; Oszczypko and Oszczypko-Clowes 2003). Within the PKB area, marine sedimentation still continued in a piggyback basin in the vicinity of Nowy Targ in the Early and Middle Miocene (Cieszkowski 1992). Lower Miocene deposits were also described from the Rača Subunit of the Magura Nappe (Oszczypko et al. 1999; Oszczypko and Oszczypko-Clowes 2002) and from the Małe Pieniny Mts. (Oszczypko and Oszczypko-Clowes 2014). Within the PKB area, these sediments are strongly folded.

Towards the end of the time of formation of the Outer Carpathians, dextral shearing occurred along NNW-SSE fault zones in the basement of the foredeep i.e. in the North-European Platform, These zones were reactivated repeatedly since late Carboniferous times but the most 
intense deformation took place during the Late Cretaceous to Early Neogene and was connected with regional compression (Scheck et al. 2002). The faults are sub-parallel to the Teisseyre-Tornquist Zone (TTZ; i.e. Świdrowska and Hakenberg 2000; Mazur et al. 2015). One of them (Fig. 1a) was the so-called Kraków-Myszków fault zone, representing a continuation of the boundary between the Upper Silesia and Małopolska blocks under the frontal Carpathians (Buła and Żaba 2008). During the reactivation of this fault zone in the Miocene andesite dykes were emplaced in the front of PKB (Jurewicz 2005; Nejbert et al. 2012).

In a lithostratigraphic sense, the sediments of the PKB are divided into two complexes: (a) a mainly carbonatic rigid complex of Middle Jurassic - Lower Cretaceous age; (b) a ductile complex composed of shales, marls and flysch of Late Cretaceous age and of a stepover basin of flysch deposits. This contrasting lithology is responsible for the later disintegration of the PKB into isolated klippen during an intense multistage tectonic evolution (e.g. Andrusov 1938; Nemčok et al. 1989; Nemčok and Nemčok 1994; Plašienka 2003). Due to later sedimentation and deformation connected with the evolution of the Outer Carpathians, the tectonic structure of the PKB became even more complex and diapiric in nature (Birkenmajer 1959), giving rise to even more contradictory explanations of its origin.

\section{Review of previous work}

The origin and tectonic evolution of the PKB have been extensively debated for decades in the Carpathian literature. The review of the most important studies exemplifies the complexity of the structure of the PKB and illustrates the changing views regarding evolution, age of folding and relationship to the Outer Carpathians bordering it to the north.

Andrusov (1968) assumed, in view of the transgressive position of the Senonian Upohlava conglomerates, that thrusting in the PKB was connected with the Late Cretaceous (Coniacian) "Subhercynian" phase. Later (Andrusov 1974) this author accepted the intra-formational character of these conglomerates as members of continuous Cretaceous PKB successions and promoted the end-Cretaceous to Early Paleogene "Laramian" phase as the main nappeforming stage in the PKB.

Large-scale geological surveys in the PKB have been conducted by Birkenmajer and his team since the beginning of the 1950s. The results of these studies were presented in numerous publications (Birkenmajer 1963, 1970, 1977, 1979, 1986, 2001; Birkenmajer et al. 2008, and references therein). According to Birkenmajer (op. cit.) the present-day structure of the PKB is a result of four tectonic stages:

(a) Late Cretaceous ("Subhercynian") north verging thrust folding, during which sedimentary sequences of the PKB (Pieniny, Branisko, Niedzica, Czertezik, and Czorsztyn) were transformed into more or less individual tectonic units. Simultaneously, synorogenic flysch deposition took place ("older klippen mantle"-Jarmuta Formation, e.g. Birkenmajer 1977, 1986).

(b) Early Paleocene ("Laramian") back thrusting of sediments from the Peri-Klippen zone of the Magura Basin onto the Czorsztyn Unit and formation of the "Grajcarek Unit".

(c) Early Miocene ("Savian") refolding of the PKB Cretaceous nappes together with the Maastrichtian klippen mantle and the Magura autochtonous Paleogene ("younger klippen mantle"), strike-slip movements along the northern and southern boundaries of the PKB and development of the megabreccia and mega-boudinage (klippen structures). During this phase, the horst structure of the PKB did form.

(d) Middle Miocene ("Styrian") compression and development of transversal strike-slip faults cutting the PKB and the southern part of the Magura Nappe.

A different point of view regarding the age of folding and location of the sedimentary basins was given by Sikora (1962, 1970, 1971) and Morgiel and Sikora (1975). They distinguished two additional sedimentary basins: the Hulina Basin (northward of the PKB basin) and the Zlatne Basin (southward of the PKB basin) and questioned the Paleocene back thrusting of the "Grajcarek Unit" over the PKB.

Another alternative interpretation was proposed by Książkiewicz (1977) who distinguished two nappes: the lower-Czorsztyn nappe (Czorsztyn, Czertezik and Niedzica successions, the Sub-Pieniny Nappe sensu Uhlig 1907) and the upper-Pieniny Nappe (Branisko and Pieniny successions), folded together. The lower nappe is smaller and composed of small thrust-sheets and blocks, whereas the upper nappe comprises large folds and thrust sheets. Książkiewicz (1977) regarded Late Cretaceous and Early Paleocene movements in the PKB as vertical only, not orogenic in nature. According to him, the main phase of deformation took place during the Oligocene to Early Miocene, Srnanek and Salaj (1965) and Ratschbacher et al. (1993) expressed the same opinion according to which "the Pieniny Nappe was thrust over the imbricated Czorsztyn Nappe, and the latter onto the Peri-Klippen Magura zone" during that time.

For Nemčok (1990a, b) and Nemčok et al. (1989) all the klippen of the $50 \mathrm{~km}$ long sector of the PKB in East 
Slovakia are olistoliths. These olistoliths are mainly composed of the Oravic Unit (Czorsztyn s.l, or Sub-Pieniny Unit) resting within a chaotic breccia belonging to the Central Carpathian Paleogene Basin (CCPB) deposits and thrust over the Magura Nappe.

In 1984, Golonka and Raczkowski asserted that Maguralike sediments inside the PKB crop out in tectonic windows but they did not show the locations in map view and crosssections. Their idea was well correlated with deep borehole data in Hanušovce (East Slovakia), where units of the PKB were indeed found thrust over Magura flysch at a distance of a few kilometers (Leško et al. 1984). The concept of back thrusting of the Grajcarek Unit over the PKB was also questioned by Jurewicz (1994, 1997, 2005), who showed that in the Małe Pieniny Mts. the klippen units were thrust over the Magura Nappe.

Studies conducted for decades in the PKB and the Carpathians by Plašienka produced both detailed descriptions of particular sections of the PKB and synthetic geotectonic theories outlining the evolution of the Western Central Carpathians (Plašienka 1996, 2003; Froitzheim et al. 2008; Plašienka 2011, 2012a, 2012b; Plašienka and Soták 2015). In the eastern Slovakian PKB Plašienka (2011) and Plašienka et al. (2012) identified what they called Šariš Unit (earlier the Fakl'ovka Unit; Plašienka and Mikuš 2010), considering it to be a lowermost tectonic unit of the PKB, overlain by Sub-Pieniny and Pieniny nappes. This Šariš Unit includes Maastrichtian-Lower Eocene synorogenic flysch to wildflysch deposits (Jarmuta/Proč Formation), which do not represent the so-called "klippen mantle" of Birkenmajer (1986), but constitute a structurally independent unit (Plašienka 2011).

In 2005, near Stará Lubovňa (Eastern Slovakia), Oszczypko et al. (2005) discovered the Early Miocene Kremna Formation, which is the youngest member the Magura succession. In later years the Kremna Formation has also been found in the foreland of the Małe Pieniny Mts. (Oszczypko and Oszczypko-Clowes 2010) and inside the PKB (Oszczypko et al. 2010; Oszczypko and OszczypkoClowes 2010, 2014). According to the latest idea of Oszczypko and Oszczypko-Clowes (2014) the nappes of the klippen belt were thrust over the Kremna Formation, which would indicate a post-Early Miocene age of thrusting within the PKB.

Evidently, although the PKB has been the subject of numerous studies, the combination of its complicated structure and composition, as well as the usually poor condition of the outcrops, has resulted in never-ending problems, which need further investigation. The following chapters provide a new interpretation of well-known facts, an attempt to account for deep structures rooted in the older basement of the foredeep, and, an analysis of the events affecting neighboring tectonic units, in order to try understanding structure and evolution of the PKB.

\section{Evolution of the Pieniny-Subpieniny basin during the Jurassic-Paleocene}

During the Late Jurassic-Early Cretaceous, widespread extension within the North-European Platform was linked to the eastward lateral propagation of the Alpine Tethys rift (Dumont et al. 1996), which resulted in the development of the Outer Carpathian basins (e.g. Golonka and Krobicki 2004; Csontos and Vörös 2004, Froitzheim et al. 2008 and references therein). Paleofaults in the epi-Variscan platform of which the Teisseyre-Tornquist Zone played a key role (TTZ; Fig. 1a) (i.e. Mazur et al. 2015; Gawęda et al. 2017) probably influenced the pattern of rifts and transform faults. The rift probably had a WSW-ENE trend (Fig. 2) and was oblique to the North Tethyan margin in the Carpathians (see Plašienka et al. 1991; Golonka and Krobicki 2001; Aubrecht and Túnyi 2001). Lithospheric stretching and crustal thinning resulting from normal listric faulting also took place within the former continental crust of the Czorsztyn Ridge. Sedimentation was dominated by extensional tectonics accompanied by block motions responsible for graben-horst formation and the resulting morphological escarpments (Weissert and Bernoulli 1985). A general scheme of the lithostratigraphy, illustrating the relationships between the klippen (Sub-Pieniny) and PeriKlippen Grajcarek and Magura) basins is presented in Fig. 3. The development of the Czorsztyn Ridge is documented in the stratigraphic data of Wierzbowski (1994), Aubrecht et al. (1997, 2006), Aubrecht and Túnyi (2001), Barski et al. (2012) and Segit et al. (2015). The characteristic feature of the Czorsztyn Basin is its paleotectonic activity and its differentiation regarding sedimentation. The large-scale mobility of this area during rifting is proved by the presence of different sedimentary hiatuses. One of the largest hiatuses, lasting from the Bajocian to the Albian (Jurewicz 1994, 1997), appears locally in the Małe Pieniny within the Homole Block. In an other place, but within the same tectonic block, the hiatus only lasts from the Hauterivian to the Albian. Local submersion caused by drowning of tectonic blocks was sometimes accompanied by neptunian dykes, the presence of sedimentary breccias (Birkenmajer 1963; Jurewicz 1997) and the appearance of exotic fragments (see: Birkenmajer et al. 1960; Jurewicz 2005). In the Bajocian, below scarps and morphological margins, crinoid limestones were most probably formed as heap deposits (Wierzbowski et al. 1999). The Czorsztyn Basin reached its maximum depth at the end of the Late Jurassic (Birkenmajer 1986). Al these processes were the result of ongoing intense crustal thinning in the basement 


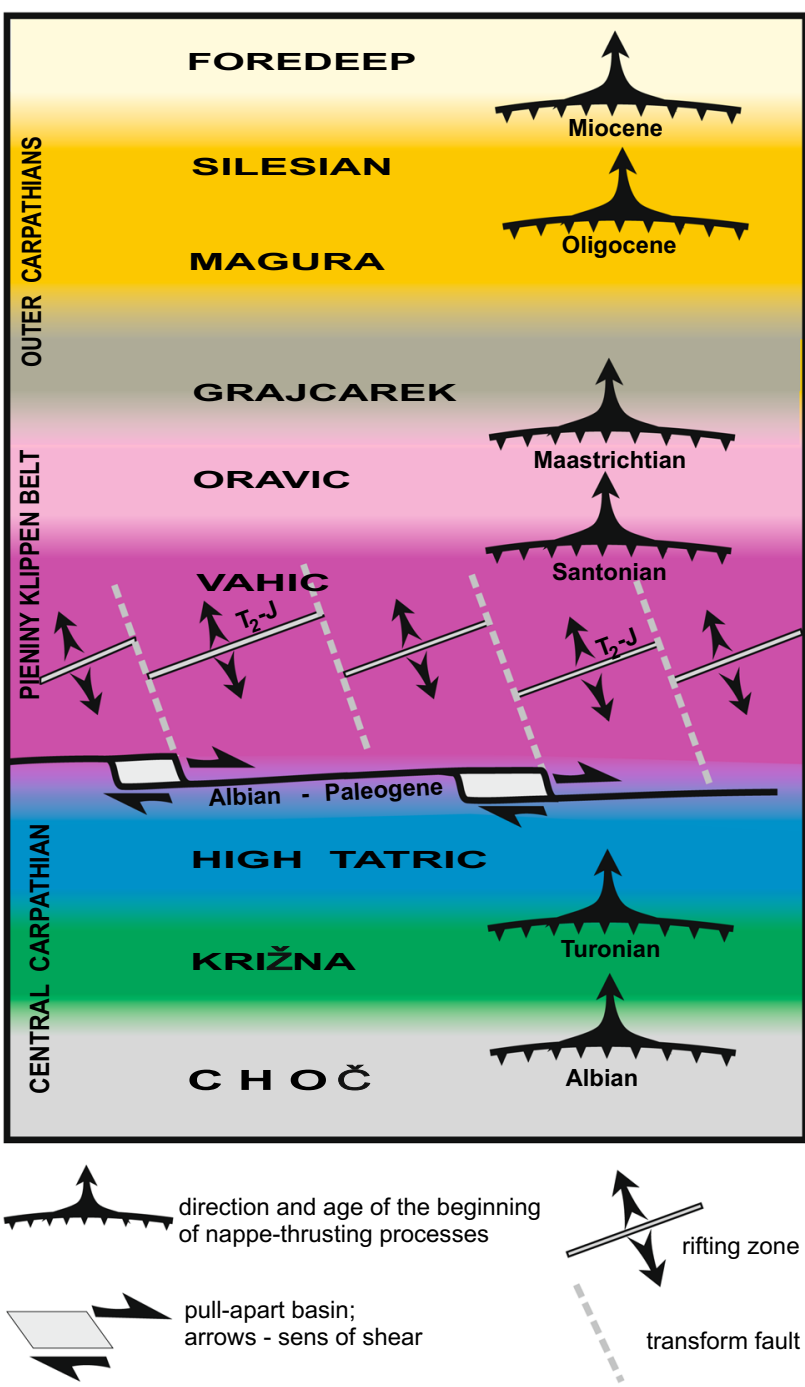

Fig. 2 Sedimentary zones and age of the beginning of nappethrusting processes in the northern Central Carpathians (Tatricum), Pieniny Klippen Belt and Outer Carpathians during the Late JurassicNeogene. Not to scale; completed after Jurewicz (2005)

of the Czorsztyn Basin. Towards the end of the Bajocian (Fig. 3), the Czorsztyn ridge was submerged and destroyed, resulting in pelagic sedimentation of ammonitico-rosso type (Wierzbowski et al. 1999; Gedl 2008; Barski et al. 2012; Segit et al. 2015).

In the southern, deeper, part of the PKB basin, i.e. Pieniny zone s.l., a deepening trend is also apparent in the sedimentary record; the basin reached its maximum depth in the Middle/Late Jurassic with deposition of black manganese radiolarites (Birkenmajer 1977). In the Mid-Late Cretaceous, there was no trace of the Czorsztyn Ridge in the morphology of the basin floor: conditions for sedimentation and, subsequently, facies were uniform over the entire PKB basin, including the Vahic (Vahic-Oravic Basin) (Birkenmajer 1977, 1986, Golonka and Krobicki 2001). Hemipelagic sediments, with globigerinids and radiolarians (Birkenmajer 1977) formed over the entire basin. When the Czorsztyn Ridge drowned, the Grajcarek Basin lost its distinctive character and became a PeriKlippen part of the Magura Basin (Fig. 3). In the Coniacian pelagic sedimentation switched into flysch deposition, preorogenic in nature (Sromowce Formation), but coupled with nappe thrusting in the Fatric-Tatric belt located to the south (Fig. 2) (Birkenmajer 1986; Nemčok and Nemčok 1994; Plašienka 2003; Froitzheim et al. 2008). The diachronic position of this pre-orogenic flysch and increasingly younger ages to the north documented northwards migration of nappe movement from the Meliata-Hallstatt to the Penninic-Vahic oceanic zones (Plašienka 1996). Within the PKB, Late Cretaceous folding started in the future Klape Unit to the south during the Coniacian-Early Santonian, migrating to the Pieniny Basin and to the SubPieniny Basin during the Campanian-Maastrichtian (Scheibner 1968; Birkenmajer 1970). At the Cretaceous/ Paleogene turn tectonic activity spread further and intensified within the PKB basin. At this time the pre-Mesozoic basement of the PKB (Vahic-Oravic) became fully subducted and the Klippen Belt represented a stack of imbricated cover thrust-sheets building an accretionary prism bordering the northern limit of the Central Carpathians Block (Figs. 2 and 3) (e.g. Froitzheim et al. 2008 ). This stage of the tectonic evolution led to the deposition of the tectono-sedimentary Gregorianka Breccia, first occurring in the Maastrichtian in the Sub-Pieniny Unit (e.g. Nemčok et al. 1989; Plašienka 2012a) and the similar Jarmuta-Proč Formation in the Peri-Klippen part of the Magura Basin (Birkenmajer 1977; Birkenmajer and Dudziak 1991; Nemčok and Nemčok 1994; Jurewicz 1997; Baková and Soták 2000; Plašienka et al. 2012). Nappe emplacement within the PKB originated at around sea level or above; these processes were accompanied by erosion and formation of synorogenic, locally shallow-marine or fresh-water, sediments (Plašienka et al. 1997). In the terminal phase of nappe emplacement, due to favourable paleomorphology (accretionary prism on the south and deep Magura Basin on the foreland), the northernmost units of the PKB were transported by gravitational sliding, and fragmented into slices, slides, olistoliths and breccias, forming chaotic sediments. The Jarmuta-Proč Formation was composed of material coming from the folded klippen units and exotic fragments, e.g. basalts occurring in the Biała Woda Gorge in the Małe Pieniny Mts. (Birkenmajer and Pécskay 2000b). The chaotic nature of these sediments is clearly visible in the Czarna Woda Stream (Online Resource 1) originating by gravitational slumping and mass movement. In one case it is a convolute fold of loosely consolidated layer of sandstone formed by a gravity-driven debris flow consisting mainly of mudstone with numerous rounded pebbles (Online Resource 1a). In the middle part of this 
conglomeratic unit Middle Paleocene foraminifera and coccoliths (NP 5 zone) have been found by Birkenmajer and Dudziak (1991).

The complex evolution of the Sub-Pieniny Basin (future Czorsztyn Unit s.l.) is responsible for the lithological juxtapositions and considerable thickness variations that, during subsequent nappe emplacement, favored slicing and fragmentation of the Sub-Pieniny unit into blocks. Książkiewicz (1977) had already distinguished two subzones within the present Czorsztyn Unit s.s.: a northern „blocky” unit (Mašlienka Subunit of Plašienka and Mikuš 2010) and a southern „imbricated” unit (Jarabina Subunit, op. cit.). In the Małe Pieniny Mts., structural analysis shows the gravitational character of nappe emplacement. One of the largest olistoliths (Homole-Biała Woda Block), composed of the plate-like Czorsztyn unit and the Niedzica unit thrust over and folded outcrops in this region (Jurewicz 1994, 1997). These units, together forming a mega olistolith (Online Resource 2) overlie the folded PeriKlippen Magura nappe, composed of Aalenian-Paleocene sediments (cf. Birkenmajer 1970; Birkenmajer and Dudziak 1991; Jurewicz 1997; Oszczypko and OszczypkoClowes 2014). Thrusting of the Niedzica Unit onto the Czorsztyn Unit occurred by gravitational gliding, which is indicated by e.g. folding against morphologic barriers and the large number of normal faults (Jurewicz 1994, 1997). Subsequently, the Homole—Biała Woda Block, sided gravitationally into the deep Magura Basin located to the north. Sediments of the latter, in its Peri-Klippen part, have been partially folded and sliced. Note that deformation, folding as well as faulting in the nearest neighborhood of the PKB was stronger in the south and gradually disappears northward.

\section{Evolution of the PKB and Magura Nappe borderland during the Cenozoic}

Although the klippen units are usually highly tectonized, it is, in most cases, easy to determine their affinity to stratigraphic successions and structural units. The contrary, however, is true for the Grajcarek Unit. Defining it and determining its northern limit in Poland have always been problematic. This unit was initially defined by Birkenmajer $(1970,1977)$ as part of the Peri-Klippen deposits of the Magura Basin. According to him these deposits became back-thrusted over the autochthonous Sub-Pieniny Unit (Czorsztyn and Niedzica) during the Early Paleocene (Laramian). In the Pieniny Mts. this Grajcarek Unit appears only along the northern boundary of the PKB, while eastward, in the Małe Pieniny Mts., sediments of this unit are found between individual klippen units inside the PKB. According to Birkenmajer (1970, 1977), the Grajcarek Unit would in fact be in the relatively highest tectonic position and its outcrops inside the PKB would be remnants of a back-thrusted nappe. Birkenmajer and Dudziak (1991) concluded that: "the upper part of the Jarmuta formation (NP 7-9) overlaps in age with the lower part of the succeeding Szczawnica Formation (NP 7-11)". However, in their map (Fig. 3 in their cited paper), the contact between both formations is drawn as a tectonic limit, separating the Outer Carpathians from the PKB. In the field, however, in several outcrops along streams flowing over the Jarmuta Formation and Szczawnica Formation such a clear limit cannot be seen. It does not stand out as neither as a strong lithological contrast nor as a change in the dip of bedding. There is no fault or any other tectonic structure present. Also such a contact is not recognizable as a geomorphological feature.

Eastward of the Polish part of the PKB, in Slovakia, the Šariš Unit has been distinguished by Plašienka (2011) and Plašienka et al. (2012) as a semi-counterpart of the Grajcarek Unit in Poland. Earlier the Šariš Unit was named Fakl'ovka unit (Plašienka and Mikuš 2010). According to the authors cited above the Šariš Unit is the lowermost structural element of the PKB; it is composed of Upper Cretaceous shales and Maastrichtian-Lower Eocene clastic sediments, capped by the chaotic breccia with olistoliths. After sedimentation, thrusting began during the Paleocene and ended in the Lower Eocene. The Sub-Pieniny Unit was thus thrust over the frontal Jarmuta-Proč Basin of the later "Šariš Unit". This is recorded by the newly defined Milpoš Breccia, composed of variegated material derived from the Sub-Pieniny and Pieniny units (op.cit.). According to Plašienka (2012a), the northern border of the PKB within the Lubovnianska Vrchovina Highland is defined by the out-of-sequence Rozdiel Fault, forming the contact of the Šariš Unit with the Magura Nappe.

The positioning of the Grajcarek or Šariš Unit became even more problematic after Oszczypko and OszczypkoClowes (2010) found Miocene sediments inside the PKB. Earlier, the same sediments were supposed to be autochthonous Paleogene, synchronous with sedimentation in the Central Carpathians Paleogene Basin south of the PKB (Horwitz 1935, Andrusov 1938; Birkenmajer 1986) that is of Eocene-Oligocene age (e.g. Bieda 1959, 1963; Alexandrowicz and Geroch 1963; Olszewska and Wieczorek 1998; Gross et al. 1984; Gedl 1999, 2000). Oszczypko and Oszczypko-Clowes (2014) considered them to represent the youngest sediments of the Magura Nappe, thrust over by other klippen units together with the Grajcarek Unit". The consequence of this assumption is a considerable rejuvenation of thrusting and folding within the PKB by coupling it to the evolution of the Outer Carpathians. This newest concept by Oszczypko and 


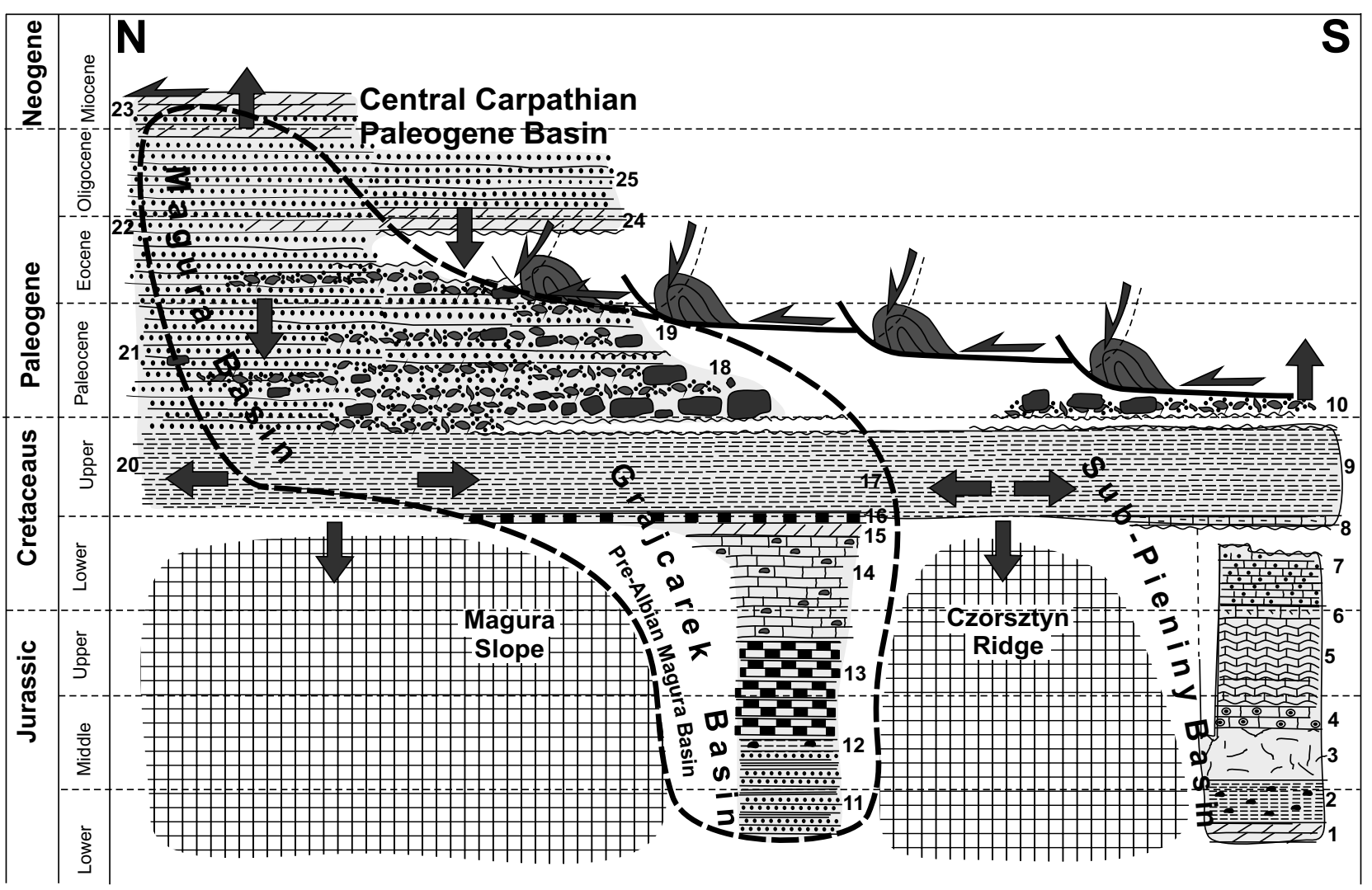

Magura Basin, formations:

$\because 23 \div$ Kremna; Upper Oligocene - Lower Miocene
$\because 22 \div 0$ Magura; Eocene - Oligocene
$\because 21 \div 9$ Szczawnica; Maastrichtian - Eocene
$\because 20$ - Hulina and Malinowa; Albian - Campanian

Grajcarek Basin, formations:

무웜 Proč (with Milpoš Breccia Member);

1...:- Paleocene - Lower Eocene

$\therefore$ Hałuszowa and Jarmuta; Campanian — Paleocene

Hulina and Malinowa Shale; Albian - Campanian

16- Wronine; Albian

15 Kapuśnica; Aptian

14. Pieniny Limeston; Tithonian - Barremian

13. Sokolica and Czajakowa Radiolarites;

㕍12蓒 Opaleniec; Upper Bajocian — Lower Callovian

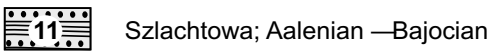

Lithology:

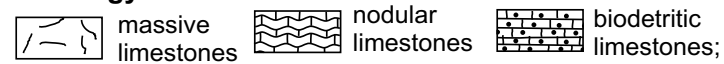

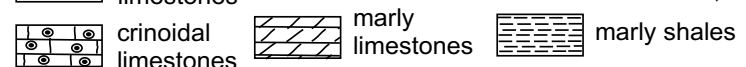

cherty
limestones
Central Carpathian Paleogene Basin, formations:

\begin{tabular}{ll}
\hline 25 & Malcov (Mniszek Member); \\
Upper Eocene - Lower Oligocene & \\
$\because 24 \div: 0$ Magura; Oligocene
\end{tabular}

Czorsztyn Basin, formations:

\begin{tabular}{|c|c|}
\hline$\therefore 10 \%$ & $\begin{array}{l}\text { Jarmuta and Gregorianka Breccia } \\
\text { Maastrichtian - Lower Paleocene }\end{array}$ \\
\hline 辰亘 & Jaworki; Cenomanian - Campanian \\
\hline & Chmielowa and Pomiedznik; Albian \\
\hline 咅7 & $\begin{array}{l}\text { Lysa and Spisz limestones; } \\
\text { Berriasian - Hauterivian }\end{array}$ \\
\hline$Z^{7} 6$ & $\begin{array}{l}\text { Dursztyn Limestone; Lower } \\
\text { or Middle Thitonian - Lower Beriassia }\end{array}$ \\
\hline 岱5 & $\begin{array}{l}\text { Czorsztyn Limestone; } \\
\text { Bathonian - Middle Thitonian }\end{array}$ \\
\hline$\frac{10}{60}$ & $\begin{array}{l}\text { Krupianka Limestone; } \\
\text { Upper Bajocian - Bathonian }\end{array}$ \\
\hline - & $\begin{array}{l}\text { Smolegowa Limestone; } \\
\text { Middle-Upper Bajocian }\end{array}$ \\
\hline & $\begin{array}{l}\text { Skrzypne Shale; } \\
\text { Upper Aalenian — Middle Bajocian }\end{array}$ \\
\hline 这公 & $\begin{array}{l}\text { Krempachy; } \\
\text { Pliensbachian - Upper Aalenian }\end{array}$ \\
\hline
\end{tabular}

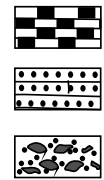

radiolarites

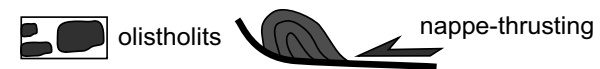

sandstones
(flysch sediments); successions

conglomerates

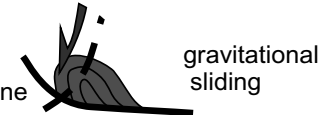


4Fig. 3 Generalized lithostratigraphy and relationships between the klippen and Peri-Klippen basins. Lithostratigraphy after Birkenmajer 1970, 1977, Birkenmajer and Gedl 2017, Barski et al. 2012; Plašienka et al. 2012; and Oszczypko and Oszczypko-Clowes 2014, simplified and changed

Oszczypko-Clowes (2014) regarding the position of the Grajcarek Unit and its relationship to the PKB, is difficult to accept. Information provided in the text of their paper implies that the PKB is separated from the Magura nappe by the Grajcarek Unit, the definition of which is partly analogous to that of Birkenmajer (1970, 1979). The Grajcarek Unit is composed of Jurassic and Lower Cretaceous sediments, similar to the profile of the Branisko unit, but with a reduced thickness, which originated in a basin located to the north of the Czorsztyn ridge. One difference concerns the age and position of the so-called black flysch (Szlachtowa Formation), which Oszczypko and Oszczypko-Clowes (2014) considered being of Cretaceous age (Aptian-Albian, e.g. Oszczypko et al. 2012), although Birkenmajer, since the 1960s, argued for an Early Jurassic age (Birkenmajer and Pazdro 1968; Birkenmajer 1977, 1979; Birkenmajer et al. 2008; Birkenmajer and Gedl 2017). According to Oszczypko and Oszczypko-Clowes (2014) the formation of black flysch was preceded by deposition of the so-called Cenomanian Key Horizon (Sikora 1962; Uchman et al. 2013), overlain by marly sediments merging upwards into the Jarmuta Formation.

As for the position of the Grajcarek Unit, Oszczypko and Oszczypko-Clowes (2014) stated that: "A characteristic feature of the Małe Pieniny Mts. is the presence of the Grajcarek Unit, located in the contact zone between the PKB and the Magura Nappe to the north". The same was put forward as a first conclusion in their work: „Along the northern border of the Małe Pieniny Mts. the PKB is separated from the Magura Nappe by a narrow, strongly tectonically deformed zone belonging to the Grajcarek Unit". Nevertheless, the maps and cross-sections by Oszczypko and Oszczypko-Clowes (2014; see Figs. 2 and 10 in their paper) show that the Grajcarek Unit always crops out as tectonic remnants that form two belts. A northern belt is made of isolated remnants thrust over the Kremna formation belonging to the Magura Nappe; a southern belt is made of "sheets of Grajcarek Unit" and subcropping klippen units that together overlie the Magura Nappe. The difficulty with this concept is that, if the Grajcarek Unit, along with the klippen units, exclusively occurs as tectonic remnants thrust over the Magura Nappe, this unit cannot separate the PKB from the Magura Nappe.

Another controversy regarding the Grajcarek Unit is its northern boundary, i.e. its contact with the Magura Nappe. Judging from the map of Oszczypko and Oszczypko-Clowes (2014) (their Figs. 2 and 10) this limit is a high-angle fault cutting the northern limit of the Grajcarek Unit thrust over the Magura Nappe. It is marked at the contact of the Jarmuta Formation (Maastrichtian-Paleocene) belonging to the Grajcarek Unit with the Kremna Formation (Lower Miocene) belonging to the Magura Nappe. Outcrops of the Kremna formation were considered by Birkenmajer (1970, 1977) and Birkenmajer and Dudziak (1981) to belong to the Szczawnica and Magura formations (Eocene-Miocene). The cross-sections do not imply that the fault cutting off the northern limit of the Grajcarek Unit slices thrust over the Kremna Formation was a deep-rooted tectonic zone (see: Birkenmajer et al.1979). This fault formed within the Magura Nappe after the Early Miocene, that is, after deposition of the Kremna Formation (after the Burdigalian and after overthrusting it by the PKB). The problem with the concept of Oszczypko and Oszczypko-Clowes (2014) is not only the Grajcarek Unit but also the fact that the PKB in the Małe Pieniny, according to them, exists exclusively as tectonic remnants that together with the Grajcarek Unit are „drifting over” the Kremna formation. This way the PKBunderstood as a deep-rooted, semi vertical structure-disappears entirely. In order to highlight the differences in the interpretation of the geological structure according to Oszczypko and Oszczypko-Clowes (2014) and the present author, three cross-sections are shown in Fig. 4, constructed along the traces that are identical to those in the discussed work (compare Fig. 10 of Oszczypko and OszczypkoClowes 2014 and Online Resource 3).

Another problem raised by the work of Oszczypko and Oszczypko-Clowes (2014) is that they propose to include the Haligovce unit as an olistolith into the so-called Myjava Paleogene (Myjava-Hričov-Haligovka Zone: Paleocene to Eocene; e.g. Scheibner 1968; Köhler et al. 1993; Wagreich and Marschalko 1995). According to Oszczypko and Oszczypko-Clowes (2014, their Fig. 10 A-B-C and Online Resource 3a; cf. Fig. 4a in this paper), sediments of the Myjava Paleogene belong to the Branisko Succession, and the youngest sediments of the latter are cut by the olistolith of the Haligovce Klippe belonging to the highest and southernmost unit of the PKB (cf. e.g. Plašienka et al. 2012). However, it is precisely in this unit that the contact of transgressive sediments, the Súl'ov-type conglomerates of the Myjava-Hričov Group (cf. Janočko et al. 2000) is clearly visible, forming a post-nappe cover complex of Paleocene-Lower Eocene age (see Golonka et al. 2015, Plašienka et al. 2016). The map of Oszczypko and Oszczypko-Clowes (2014) suggests that the sedimentation of the Branisko unit lasted at least until the Eocene and that the age of overthrusting within the PKB is post-Kremna Formation, i.e. contemporary with overthrusting within the Outer Carpathians. This proposal is contrary to many current opinions regarding the structure and evolution of the PKB (e.g. Csontos and Vörös 2004; Plašienka 2011). 

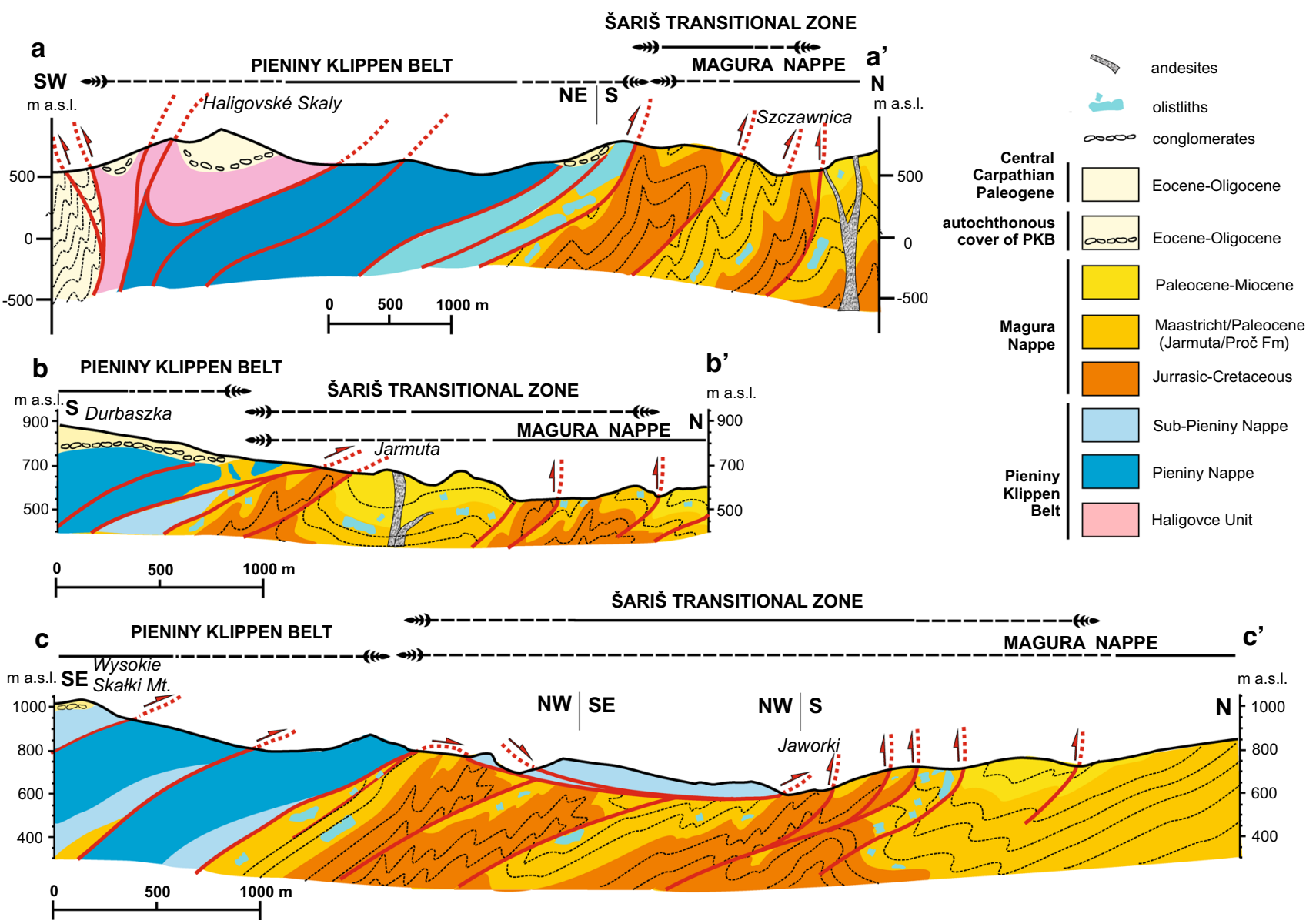

Fig. 4 Geological cross-sections across the Małe Pieniny Mts. along traces identical to those in the paper of Oszczypko and OszczypkoClowes (2014), their Fig. 10 and Online Resource 3), reinterpreted by

The Grajcarek Unit marks the boundary of two tectonic megaunits: the Central and Outer Carpathians that are commonly regarded as being in contact with each other along a steeply dipping and deep-rooted contact. It is also a surface along which, as concluded by Oszczypko and Oszczypko-Clowes (2014), the Central Carpathians Block rotated counterclockwise. Determining the reasons for the difficulties in exactly defining the Grajcarek Unit and in placing its northern limit are probably key to a sound interpretation of the tectonics and evolution of the PKB at a larger scale.

\section{The role of deep fracture zones in the underplated North-European Platform in causing tectonic diversity along the PKB}

The fold-thrust architecture of the PKB formed at the turn of the Cretaceous and Paleogene in connection with the subduction of the pre-Mesozoic basement of the the author. Sections a-c in this figure correspond to a, b, c of cited authors (see: Online Resource 3). See Fig. 1b for the location of the profiles (a-a'; b-b'; c-c')

sedimentary basin and its accretion at the front of the Central Carpathian Block. During the later stages of formation of the Carpathian orogen, namely during Late Oligocene to Miocene thrusting and folding that led to the formation of the Outer Carpathian fold and thrust belt, the North-European Platform was forced below the nascent orogen, undercutting and underplating the PKB and adjacent Tatricum units (e.g. Csontos and Vörös 2004; Froitzheim et al. 2008). Underthrusting of the NorthEuropean platform must have reached far to the south before Late Miocene roll-back and break-off the European lithosphere, as can be deduced from some $500 \mathrm{~km}$ shortening within the Outer West Carpathians (Gạgała et al. 2012). The underplated European platform basement and, especially, deep fracture zones within it, played a key role in shaping lateral variations in style of deformation and, consequently, the resulting geological structure of the PKB. The fault pattern within the North-European Platform was pre-shaped during Variscan orogeny. These faults are generally parallel to the Teisseyre-Tornquist Zone (e.g. Pożaryski 1991; Pharaoh 1999; Świdrowska and 
Hakenberg 2000; Dadlez 2006; Guterch and Grad 2006), that is they are oriented NNW-SSE. These same directions are clearly visible on the radar images in the entire Polish Outer Carpathians (Doktór et al. 2002). Among those faults, the Kraków-Myszków (Kraków-Lubliniec) (Żaba 1996; Buła et al. 1997, Buła and Żaba 2008) tectonic zone exerted the greatest impact on the geodynamic evolution of the study area. Its southern prolongation continues towards the SSE below the Outer Carpathian nappes and the PKB (Fig. 1b), reaching the Ružbachy Window and the SubTatric Fault (Jurewicz 2005, Fig. 2). In the Carpathian foreland this fault, dividing Upper Silesian from the Małopolska Block, has repeatedly been reactivated as a dextral strike-slip fault (Żaba 1996; Buła and Żaba 2008). Within the PKB this tectonic feature manifests itself in the form of the Dunajec Fault (Fig. 1b), which shifts the northern limit of the PKB units by ca. $700 \mathrm{~m}$ to the south (Birkenmajer 1979). Above this NNW-SSE fracture zone the geological map by Uhlig (1905) shows a pull-apart-like structure, now occupied by the Dunajec River. Its Miocene reactivation produced andesite intrusions (12.5-10.8 Ma; Birkenmajer and Pécskay 1999, 2000a) that intruded along subordinate Riedel shears (Jurewicz 2005, Jurewicz et al. 2007, Nejbert et al. 2012). In the vicinity of Szczawnica $\mathrm{CO}_{2}$-rich carbonate waters are found, enriched with mantle-derived helium (Leśniak et al. 1997). Geomorphical studies indicated Early Quaternary uplift of the Dunajec drainage basin the total amount of which varies from 100 to $110 \mathrm{~m}$ (Zuchiewicz 2009). This also supports the neotectonic activity of this fault. Still another argument suggesting tectonic activity of the Dunajec Fault is the presence of flowstone-like calcites within subordinate extensional fractures dated to be $6000 \mathrm{ka}$. (Jurewicz et al. 2007). Numerous mineral springs and travertines occur along the southern prolongation of the Dunajec Fault beyond the PKB, in the vicinity of Vyšné Ružbachy (Uhlig 1905). The Dunajec Fault and parallel Poprad Fault have also experienced recent seismic activity (Wiejacz 1994; Guterch et al. 2005). There is a linear (NNW-SSE-oriented) string of earthquake epicenters, extending from Krościenko in Poland up to the east of Spišská Nová Ves in Slovakia (Kováč et al. 2002). The strike-slip activity of NNW-SSE-oriented faults could be connected with $\mathrm{N}$ to NNE-oriented vectors of recent horizontal motions, observed for seismic stations located south of the Pieniny Klippen Belt, pointing to the ongoing NNE-directed push of the Alcapa block (Jarosiński 1998, 2005; Łój et al. 2009).

The deep fracture zone within the sub-Carpathian basement, correlated with the boundary between the Upper Silesian and Małopolska blocks, results in a substantially thicker Magura Nappe to the east of this zone, as the basement drops from $4 \mathrm{~km}$ (western side) to $7 \mathrm{~km}$ below the surface (eastern side; Zuchiewicz and Oszczypko 2008). The Dunajec (Kraków-Myszków) Fault is one of many faults parallel to the Teisseyre-Tornquist Zone, which had a considerable impact on the geometry and structure of the PKB (Figs. 1a, b and 5a, b). Several smaller faults parallel to the Dunajec Fault have been recognized to the east of it in the PKB and surrounding area: Kamienka Fault, Vel'ký and Malý Lipnik faults (Vabec Fault) and the more significant Poprad Fault (Piwniczna-Udol-Plaveč-Lipany). Strike-slip faults and the related geometry of shifted klippen in the Lubovnianska Vrchovina Highland is clearly documented in a geological map by Nemčok (1990a, b) and by Plašienka et al. (2012). The strike-slip motion of these faults is also visible in the field where vertical fault surfaces between isolated klippen blocks clearly show dextral subhorizontal striations.

To the east of the Dunajec Fault the PKB strike changes gradually from W-E to WNW-ENE (Figs. 1b, 5b and 6). Notably, PKB strata within this curvature strike obliquely to the overall strike of the PKB limits. This trend is clearly visible in the field in the Małe Pieniny Mts. (Jurewicz 1994), Lubovnianska Vrchovina Highland (Potfaj 1997; Plašienka 2012a), as well as east of the investigated area: e.g. Olejnikov or Drienica faults (Plašienka and Mikuš 2010). The obliquity of the bedding with regard to the PKB trend has two reasons. The first is the larger amount of thrusting and consequently greater shortening towards the east. This is observable not only at a regional level but also in the field. In the eastern part of the Małe Pieniny Mts. there is a semi-horizontal scissor fault where the amplitude of thrusting increases to the east and the normal fault throw increases to the west (Jurewicz 1994). A situation whereby bedding strike is oblique to the overall strike of the structure due to differential shortening related to folding and thrusting has been described by Allerton (1998) from the Sierra de Burete and Sierra de Quipar in Spain. A second reason for this obliquity is displacement at faults, which cut the PKB transversally (Fig. 1b). Right lateral slip within basement rocks produced characteristic fault structures within the overlying cover, i.e. strike-slip duplexes (Schlögl et al. 2008; Plašienka 2011; Plašienka and Mikuš 2010) named "ribbon klippen" (Plašienka 2012a). This relationship between the overall PKB geometry and the strike of bedding implies that the formation of the arc-like geometry of the Klippen Belt between the Central and Outer Carpathians was not due to ductile bending but instead was a product of step-like displacements along dextral faults (Fig. 5b). These displacements created the geometric effect of a bending klippen belt, accompanied by sigmoidal strata strikes, generated by drag along strike-slip fault surfaces (Fig. 6). The latter developed above a zone of deep fractures within the down-going platform (Fig. 5a, 
a

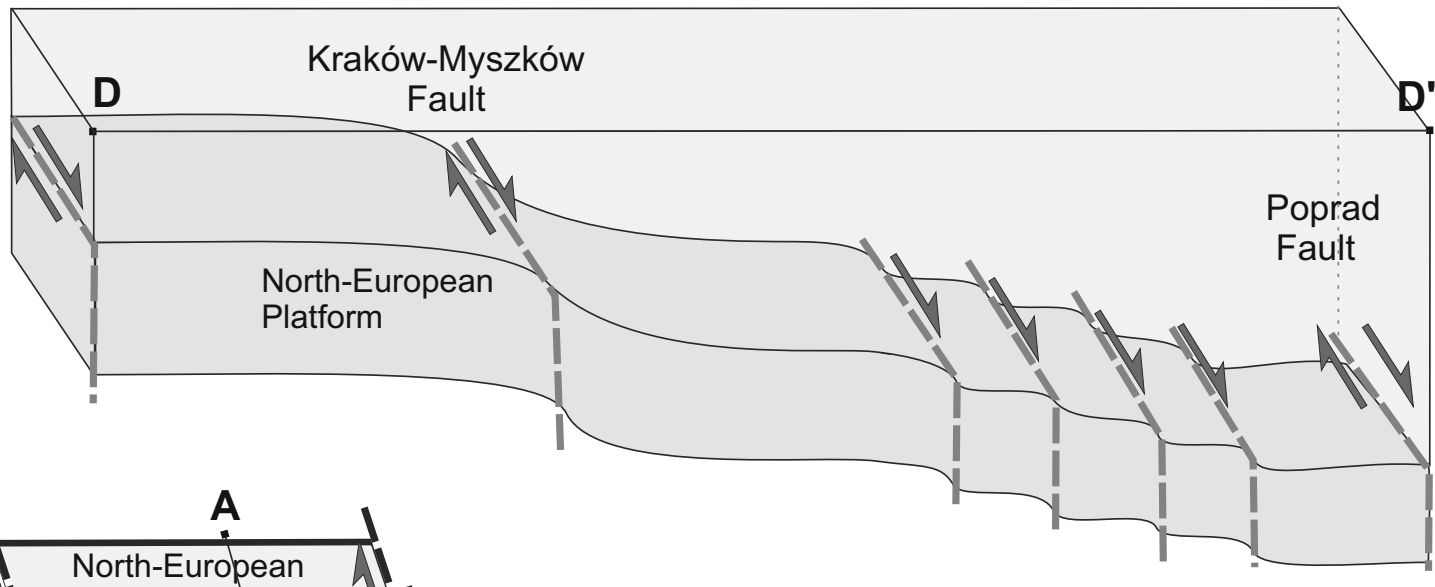

b
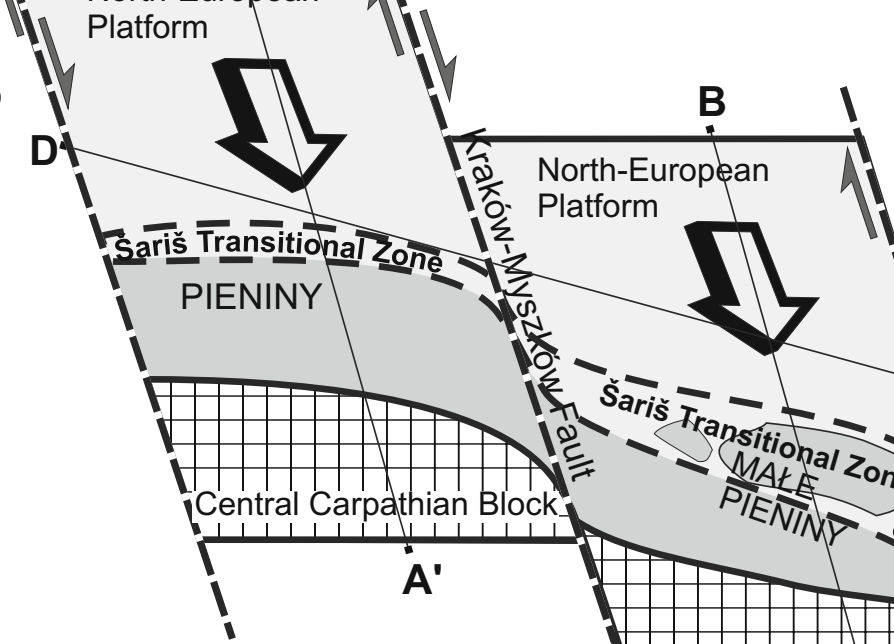

c

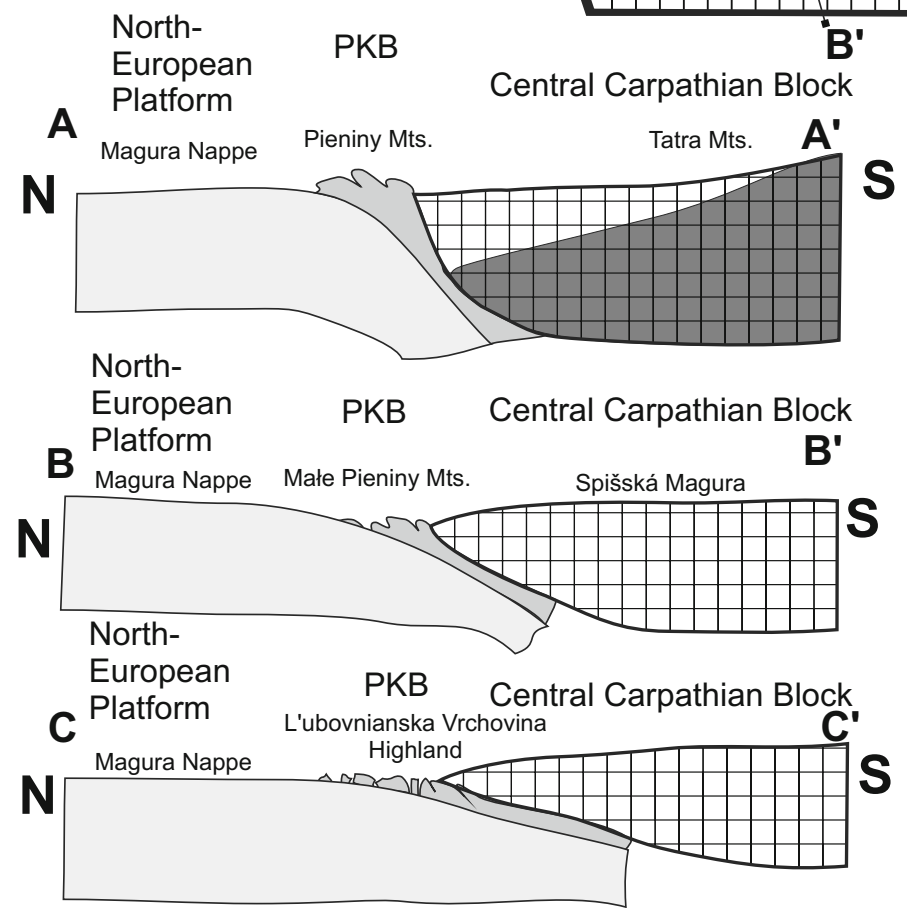


4Fig. 5 Relationship between the North-European Platform, Central Carpathian Block and the PKB trapped between them (ideograph, not to scale). a Morphology of the platform basement, deepening eastward. b Tectonic scheme showing the influence of deep fracture zones on the geometry of the PKB; Cross-section of the three segments of the PKB: c Pieniny Mts., d Małe Pieniny Mts., e Lubovnianska Vrchovina Highland

c). Their presence influenced first the process of subduction and subsequently the collision of the North-European Platform with the Central Carpathian Block (Jurewicz 2005). Due to fracture zones within the underthrusting European platform, each plate segment behaved somewhat differently during subduction and collision with the Central Carpathian Block. As a result, the PKB in the Pieniny Mts. area represents a steep structure, formed by compression between the accretionary prism of the Outer Carpathians/ North-European Platform and the Tatra Mts. massif. Inverted strata have been observed at the southern limit of the PKB, within the Central Carpathian Paleogene, in the so-called zone of the Peri-Pieniny Flexure (Mastella 1975). These are due to the structure of the Tatra Block, where rigid granitoids building up its lower part undercut the bottom of the PKB (Jurewicz 2005). Soft flysch sediments in its upper part were not sufficiently resistant and this caused the klippen belt to become overturned to the south. A similar rigid and thick southern granitic massif was absent to the east of the Dunajec Fault and the basement of the down-going North-European Platform is ca. $3 \mathrm{~km}$ deeper (Zuchiewicz and Oszczypko 2008). An effect of less steeply inclined subduction below the Central Carpathian Block and the PKB at its front is a thinner Klippen Belt predominantly consisting of northern PKB units (lack of Pieniny Unit s.s.) and the presence of the Magura Nappe below the klippen, as can be seen in tectonic windows. Additionally, slip along transverse faults was sometimes greater than the width of the klippen belt, which augmented the effect of isolated klippen. This effect is taken to an extreme in Ujak (Fig. 1b), where the PKB disappears entirely, displaced to the south by slip along the Poprad Fault and the Central Carpathian Paleogene; it is in direct contact to the sediments of the Magura Nappe (Nemčok 1990a; Plašienka and Mikuš 2010).

Activation of NNW-oriented faults within the basement of the Carpathians, responsible for the arc-like geometry of the $\mathrm{PKB}$, produced by stepping-over dextral strike-slip faults, precludes the possibility of counter-clockwise rotation of the Central Carpathians Block with respect to the Outer Carpathians continuing into the late Neogene. Activation of oblique NNW-oriented faults cutting the PKB is documented by Early Miocene andesite dyke arrays (Birkenmajer and Pécskay 1999, 2000a), filling subordinate faults branching off the Dunajec Fault (Jurewicz 2005; Nejbert et al. 2012). Paleomagnetic investigations documented a rotation of the whole Alcapa microplate in the Early Miocene, the value of which was estimated by Kovác and Márton (1998) to ca. 40-50 (see: Fodor 1995; Márton

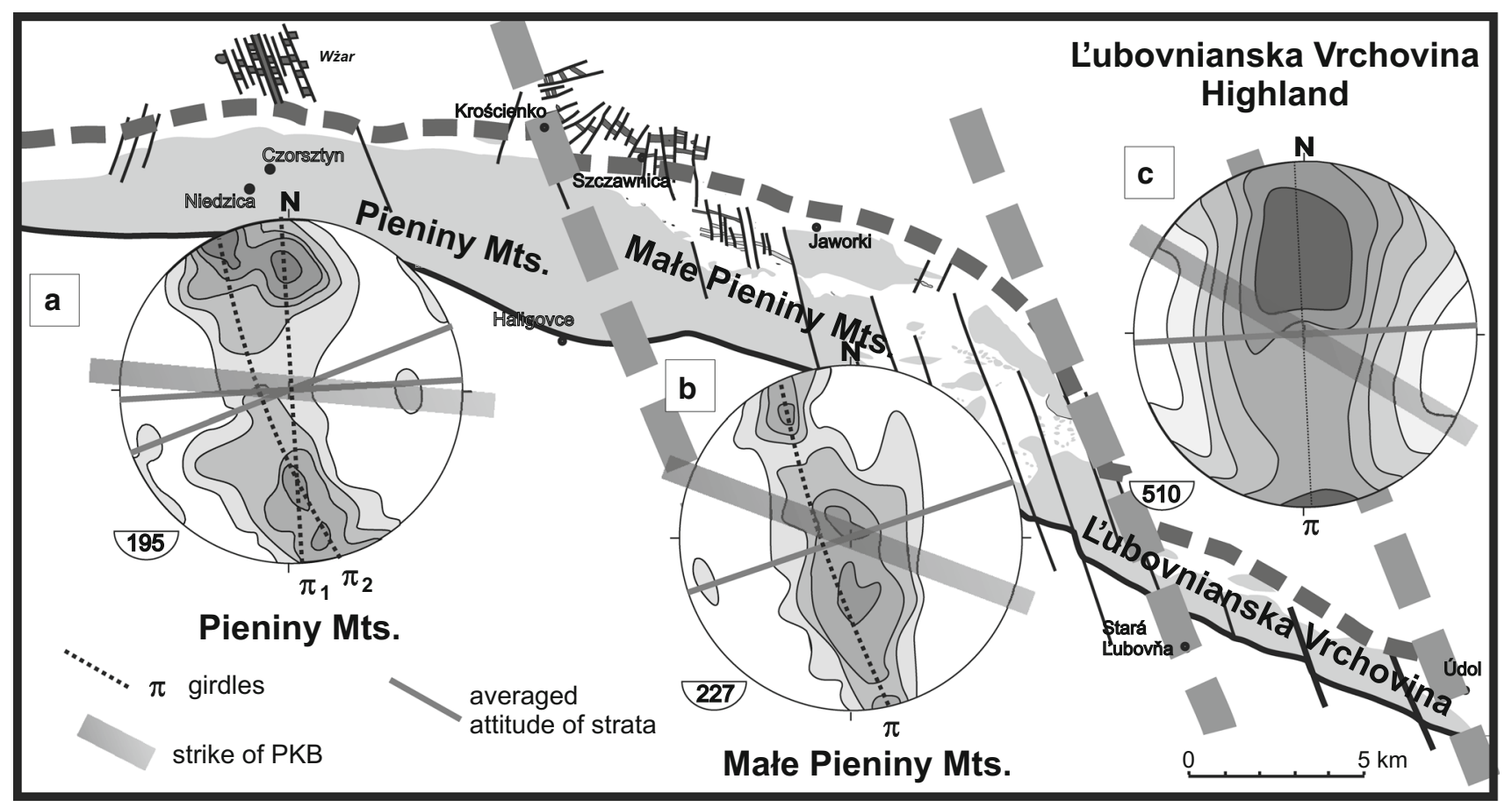

Fig. 6 Attitude of strata against the background of three parts of the PKB. a Pieniny Mts. b Małe Pieniny Mts. (see Jurewicz 1994 for more details); c Lubovnianska Vrchovina Highland (after Plašienka 2012a). Orientation of poles to planes is shown in the lower hemisphere 
et al. 1999, 2004, 2013). Paleomagnetic investigations of Márton et al. (2013) indicated a similar magnitude of CCW rotation during the Miocene for the PKB, Central and Outer Western Carpathians. Filling of the so-called Plaveč Graben with Eocene-Oligocene deep-water sediments may be evidence that this rotation was not located along the PKB (Leško 1960; Nemčok et al. 1998; Plašienka and Mikuš 2010). Rotation, and the related strike-slip zone along the PKB (Figs. 2 and 5b), could have occurred earlier as a consequence of oblique subduction at the end of the Cretaceous and beginning of the Paleocene (Tomek and Hall 1993; Zeyen et al. 2002). According to Rakús and Marschalko (1997), polyphase activity of this shear zone during the Albian-Paleocene produced diachronous pull-apart basins, e.g. the Manín or Kostelec basins. These basins could have been formed through the same mechanism as that of the Gosau basins described by Wagreich and Marschalko (1995) and Hofer et al. (2013).

In summary, the complex structure of the klippen belt is, on the one hand, the result of tectonic events within the PKB influencing the sedimentation within the Magura Basin and, on the other hand, the effect of the structure of the basement (the sub-Carpathian part of the platform) and its multiple, dextral deep fracture zones oriented NNWSSE. Both processes resulted in the presence, within the Magura Nappe, of synkinematic sediments resembling polygenetic mélange, giving rise to difficulties in the interpretation of the structure of the northern PKB borderzone.

\section{The Šariš Transitional Zone representing a suture zone between Central and Outer Carpathians: a discussion}

According to the definition of tectonic units in the sense of a definition such as given by e.g. Fodor (2004), namely that "Tectonic units are three-dimensional rock bodies with distinct physical boundaries and unique structural characters including temporal evolution", it can be concluded that the Grajcarek Unit of Poland (Sariš in Slovakia) does not fulfill this criterion.

There is no doubt that, at the time of the development of the Vahic-Oravic Basin there was, beyond the Czorsztyn ridge limiting it to the north, another basin, which was not the Magura Basin. This basin, during the Aalenian to Albian, was clearly separate from the Vahic-Oravic Basin and has been previously described as the Peri-Klippen Hulina Basin (Sikora 1971, Golonka et al. 2000), Grajcarek Basin (Birkenmajer 1970, 1986), or pre-Late Albian Magura Basin (Barski et al. 2012). Although similar in facies to the Branisko succession of the Klippen Belt, this Peri-Klippen basin also shows affinites to the Magura
Basin of the Outer Carpathians, a basin in which sedimentation initiated in that part of the Peri-Klippen zone where its oldest sediments are preserved (Fig. 3). In the Late Cretaceous, the Czorsztyn ridge ceased to be discernible in the sea bottom topography (Segit et al. 2015), the PKB basin deepened and facies became more uniform (Birkenmajer 1986). Therefore, in the Peri-Klippen zone, the pre-Late Albian Grajcarek Basin ceased to be recognizable as distinct from the Magura Basin; in the Late Cretaceous it became an integral part of the Magura Basin (Fig. 3).

Folding and thrusting took place within the VahicOravic zone at the turn of the Cretaceous/Paleogene, forming an accretionary prism that became a forerunner of the PKB (Fig. 7a). In the north, within the Magura Basin at its front, sediments could have been partly folded, sliced and eroded, but no autonomous tectonic unit formed. Newly formed denivelations favored gravitational sliding, accompanied by formation of synorogenic breccias of the Jarmuta Formation (Birkenmajer 1977, 1986; Plašienka et al. 2012). Mass motions took place at the same time, producing gravitational slides (Online Resource 1) that together with olistoliths (Online Resource 2) resulted in the formation of chaotic deposits. Clastic material could have been partly derived from the recently stacked and up thrown PKB accretionary prism and partly from the folded and eroding the Peri-Klippen Magura Basin. Within the conglomerates known from the Czarna Woda Stream the percentage of klippen rocks found as pebbles reaches $71 \%$; the remainder may be exotic material (Kutyba 1986). Olistoliths could have formed not only during sedimentation of the Jarmuta Formation. In the Paleocene the Szczawnica Formation (Fig. 3) belonging to the Magura Nappe in the Ścigocki Stream near Krościenko the olistholitic block of Jurassic and Cretaceous rocks (probably Pieniny Limestone Formation from PKB; Birkenmajer 1977) could be visible. In the same location, within the younger Zarzecze Formation of Magura Nappe, a submarine slump was recognized (Golonka and Waśkowska 2014).

After this main overthrusting event, the structure of the PKB became even more complicated. At the end of the Paleocene the PKB and its southern neighbor, the Tatricum, may have been exposed undergoing erosion (Buček 2001, Soták et al. 2001). Piggyback basins could, however, still have existed locally, with continuous sedimentation during this overthrusting, that is from Late Cretaceous until Paleocene (Myjava Paleogene-Birkenmajer 1986; Birkenmajer and Dudziak 1991; Kostka 1993). Traces of terrestrial sedimentation can be seen in the Tatra Mts. where karst has been documented (Głazek and Zastawniak 1999; Głazek 2000). At this time the PKB constituted the southern shore of the Outer Carpathian Basin, and was one 
of the sources of its clastic material, filling the Peri-Klippen part of the Magura Basin (Milpoš Breccia; Plašienka et al. 2012). During the Paleocene-Eocene Thermal Maximum (PETM; see: Storey et al. 2007) and global sea-level changes the Tatricum area was submerged, forming the CCPB (Marschalko1968; Jacko and Janočko 2000) which, after Tari et al. (1993) and Kazmer et al. (2003), is a forearc basin associated with B-type subduction of the European plate. Sedimentation within the basin started with gravels and nummulitic limestones (Borové Formation; Gross et al. 1984, Janočko and Jacko 1999). Soon, the PKB was also inundated and the CCPB sea, merged with the Outer Carpathian Basin (e.g. Książkiewicz and Leško 1959). Traces of this inundation are transgressional sediments overlying the Haligovce Unit, known as the Súl'ov conglomerate (Myjava-Hričov Group; Janočko and Jacko 1999; Plašienka 2011). The PKB was certainly a ridge at the sea bottom (Birkenmajer 1986; Jurewicz 2005) that might have shed olistoliths and supplied clastic material to the deep Magura Basin located to the north (Fig. 7b), (Milpoš Breccia; Plašienka et al. 2012, 2016). The PKB was also the source area of clastic material during sedimentation of the Szaflary and Zakopane beds of the CCPB (Gedl 2000). The continuously eroded sub-marine ridge was soon destroyed and itself became an area of deposition of flysch sediments. Their vestige is the so-called ,autochtonous Magura Paleogene" (Birkenmajer 1970, Golonka and Raczkowski 1981, 1984), known also as „,intra klippen flysch” (Horwitz 1935) or „younger klippen mantle" (Birkenmajer 1986). These sediments unconformably overlie the klippen units and are considered younger then the former. They also constitute positive morphological forms. Nonetheless, they were considered by Oszczypko and Oszczypko-Clowes (2014) as the Kremna Formation of the Magura Nappe and placed below the overthrown Grajcarek Unit, overlain in turn by the klippen units. Also, Plašienka et al. (2012) considered that Paleogene sediments within the klippen belt (except for the Sul'ov Breccia) can be seen only in tectonic windows and that they belong to the Sariš Unit. Due to the lack of convincing outcrops, it is difficult to argue decisively for either the presence of "autochthonous Paleogene" overlying klippen units (Birkenmajer 1977, 1986) or the Paleogene underlying klippen units and representing the Grajcarek/Sariš Unit (Oszczypko and Oszczypko-Clowes 2014; Plašienka et al. 2012) or the Magura Nappe. However, taking into account the scale of sinking of the Mesozoic Tatricum beds within the neighboring Podhale synclinorium, where the thickness of Paleogene sediments has been estimated by Środoń et al. (2006) to be $6.5-7.5 \mathrm{~km}$ in the Eastern Podhale and even more in the Spišská Magura area (because the basin floor was inclined towards the east), it can be deemed improbable that in an extremely tectonized structure like the PKB, the Paleogene sediments were not preserved as „klippen mantle”. A proof for this are perhaps the transgressive Súl'ov conglomerates occurring on the highest and southernmost Haligovce Unit (Janočko et al. 2000) and overstepping the Middle Eocene-Oligocene sediments of Udol Succession in the easternmost part of the study area (Plašienka and Mikuš 2010).

Overthrusting in the Magura Basin of the Outer Carpathians started in the Peri-Klippen zone in the Miocene (Oszczypko 2006, Oszczypko et al. 2015). It was related to the north-eastward movement of the Alcapa and Tisza-Dacia megaunits (Golonka et al. 2000; Csontos and Vörös 2004). The main mechanism driving subduction in the Polish Carpathians, responsible for the north-east directed nappe transport, was slab-pull, linked with the loading of oceanic or strongly thinned continental crust. The Neogene subduction zone had retreating subduction boundaries (e.g. Royden 1993; Sperner et al. 2002; Froitzheim et al. 2008). At this time the Klippen Belt was further shortened and stacked (Birkenmajer 1986; Plašienka 2002), which led to further complications at the borderzone of the PKB and Magura Nappe (Fig. 7c). The previous nappe structure underwent disintegration due to the destruction of thrust surfaces, along which further tectonic movement was not possible. Fragmentation of older overthrusts was responsible for the presence of characteristic klippen within the PKB and diapiric tectonics (Birkenmajer 1959). Due to these processes the PKB behaved like a megabreccia zone (Andrusov 1938; Ratschbacher et al. 1993; Kováč and Hók 1996).

According to Plašienka et al. (2012) olistoliths were formed during the Maastrichtian to Early Eocene (see Plašienka et al. 2016), but further reactivation of this process could have taken place later and be linked to Neogene inversion causing rotational upthrow of the Tatra block (Piotrowski 1978; Jurewicz 2005). Its southern limit was uplifted along the Sub-Tatric Fault (Uhlig 1899; Hrušecký et al. 2002; Sperner et al. 2002), and its northern limit was downthrown. At the same time, a piggy-back basin (Kremna Formation) appeared to the north of the PKB, on top of the newly formed Magura Nappe (Oszczypko 2006). Recently formed topographic denivelation could have also favored small gravitational sliding and thrusting (Fig. 7c).

Advancing orogenesis and further shortening of the Outer Carpathians resulted in reactivation of existing thrusts and formation of new thrust faults (Fig. 7d). Consequently, the previous structure of the PKB was destroyed by numerous local deformations, the appearance of small thrust-sheets and out of sequence faults. The juxtaposition of these structures on older phases of deformation resulted in the obliteration of the already complex tectonic pattern of the PKB. The Šariš Unit defined by Plašienka et al. 

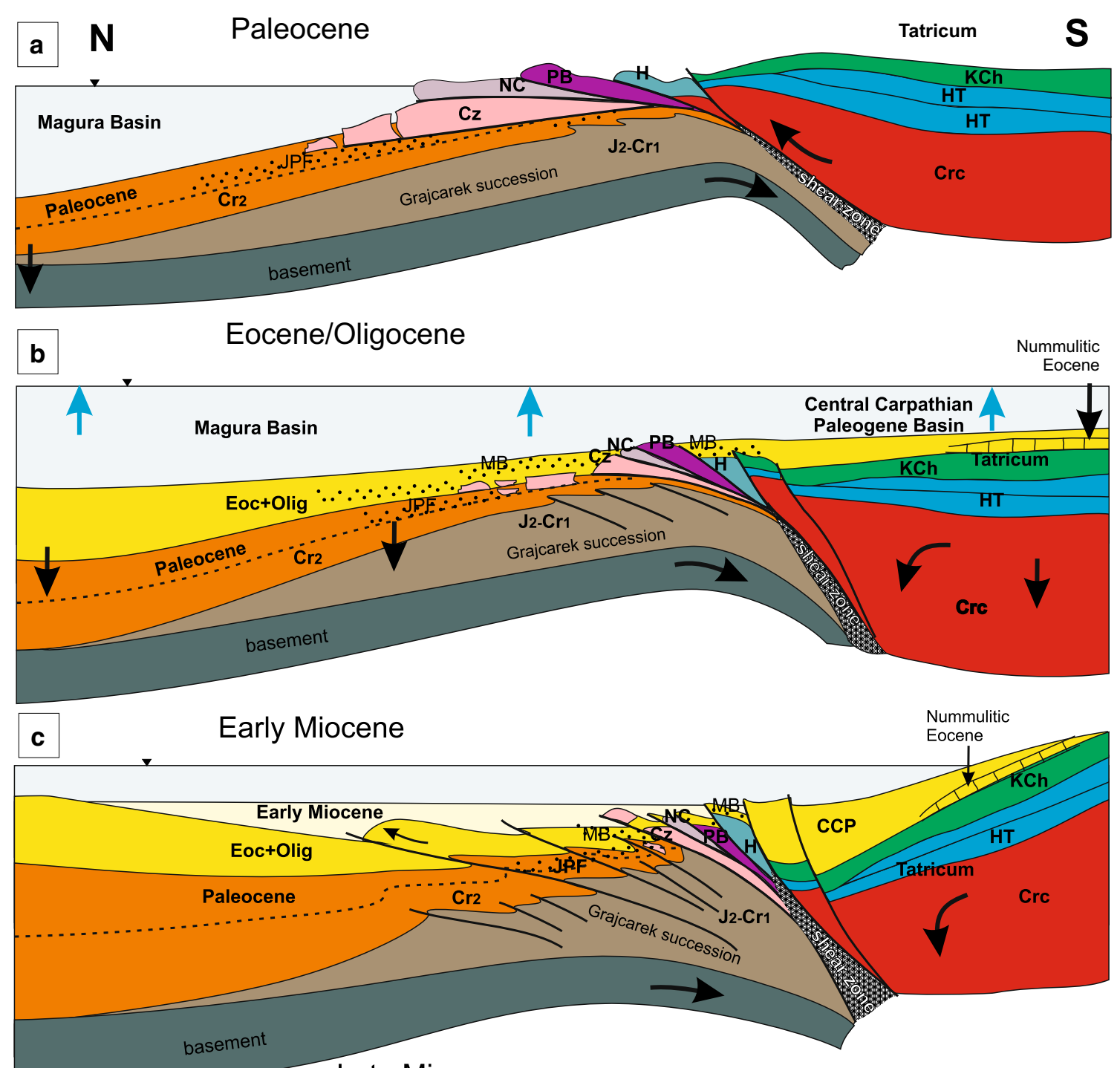

:MB: Milpoš Breccia

-JP.F. Jarmuta-Proč Fm

PKB units

H Haligovce

PB Pieniny-Branisko

NC Niedzica-Czertezik

Cz Czorsztyn

Tatricum

KCh Križna and Choč nappes

Late Miocene

d Outer Carpathians

HT High Tatric Nappe High Tatric Nappe
and autochthonous
cover

Tatra Mts.

Crc crystalline core

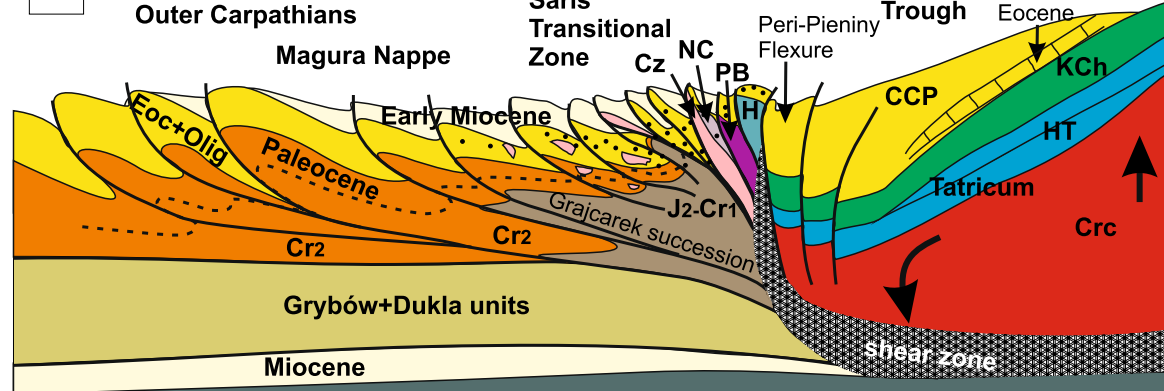

North-European Platform 
4Fig. 7 a-d Stages of the Late Jurassic to Early Miocene evolution of the Pieniny Klippen Belt and adjacent areas (sketch, not to scale) and based on Jurewicz (2005)

(2012) would have had to be differentiated at this stage, but instead of a clear tectonic limit, a series of smaller slices appeared, difficult to interpret. The Rozdiel Fault, marked on the map of Plašienka et al. (2012) as a northern limit of the $\mathrm{PKB}$, is not a homogenous fault, but is composed of fragments of oblique faults and small imbrications (Figs. $1 b$ and $5 b$ ).

Furthermore, rotational upthrow of the Tatra massif, caused by undercutting of the downgoing North-European Platform, also had other consequences. Associated downthrow of the limit of the northern Tatricum block formed the Podhale synclinorium filled with CCPB sediments (Gołąb 1959; Mastella 1975) and, along the tectonic contact with the PKB, formation of the Peri-Pieniny Flexure (Figs. 1b and 7d). Within the latter the beds are upwarped and overturned towards the south. The same occurs within the PKB, where imbricated slices formed during nappe stacking have subsequently been overturned towards the south and put into an inverted position during Neogene compression and inversion event (Mastella 1975; Birkenmajer 1977, 1986). As mentioned above, the geological build-up of the contact zone is responsible for overturning the PKB and the formation of out-of-sequence faults. The deep, resistant granitoid massif was forced towards the north, undercutting the PKB structure, while weak and only slightly lithified flysch sediments at the surface were retroturned by newly formed Outer Carpathian nappes (Fig. 5). This profound change of the tectonic regime resulted in yet another reorganization or obliteration of older structures. Thus the klippen belt was fragmented into blocks, which, accompanied by lithological variations within the klippen units (competent and incompetent rocks), produced diapiric structures (Birkenmajer 1959; see Codegone et al. 2012). As a result, in the borderzone between the Outer Carpathians and the klippen belt, one can observe the intercalation of tectonic structures formed due to multiple tectonic events such as folding, imbrication, nappe thrusting and gravitational sliding producing olistoliths and breccias. The area subjected to deformation was expanding towards the north and the youngest event was first contemporary with, and later followed, the sedimentation of the Kremna Formation (Burdigalian; Oszczypko 2006). Thus, a chaotic mélange zone was formed in front of the $\mathrm{PKB}$, a greater part of which was underthrust below the klippen units and is now observable in tectonic windows. The amplitude of this underthrusting can be seen in the field in the vicinity of Kamienka quarry (Fig. 1b), where there are outcrops of so-called ,black flysch” (Szlachtowa
Formation) connected with pre-Late Albian Magura (Grajcarek) Basin (Barski et al. 2012).

Moving from west to east, i.e. from the Pieniny Mts. through the Małe Pieniny Mts. to the Lubovnianska Vrchovina Highland, there is a gradual change in both the PKB structure and its contact with Magura Nappe (Fig. 1b). Slices and thrust-sheets build the western klippen belt and its northern limit is steep. The more we move to the east, the narrower gets the Klippen Belt, its contact with the Magura nappe is less steeply inclined, the klippen are more disintegrated, and there is a higher proportion of SubPieniny than Pieniny Unit and a greater amplitude of overthrusting onto the Magurian foreland. Towards the east, nappe units of the $\mathrm{PKB}$ are gradually replaced by loose klippen belonging mostly to the Czorsztyn Unit (SubPieniny), and considered by Plašienka et al. (2012) as part of the Šriš Unit. A common feature of these klippen is that, regardless of the transport process (tectonic thrusting or gravitational sliding), they were incorporated into the Magura Basin, becoming part of it and building a tectonosedimentary belt along the multi-stage formed PKB. Instead of the Grajcarek Unit sensu Birkenmajer (1986) and Oszczypko and Oszczypko-Clowes (2014) or the Šariš Unit of Plašienka et al. (2012) the Peri-Klippen zone of the Magura Basin i.e. Grajcarek Basin should be distinguished. This basin includes the oldest sediments of the Magura Basin, i.e. the Grajcarek succession of Birkenmajer and Gedl (2017). This same basin was named "pre-Late Albian Magura Basin” by Barski et al. (2012).

During "Laramian" folding at the turn of the Cretaceous/Paleocene, klippen units partly overthrust/gravitationally slid over this zone and clastic material from degrading folded and overthrusted klippen units filled it. Formation of a polygenetic mélange then followed, where the difference between tectonically disrupted and gravity driven chaotic bodies is invisible.

Chaotic sedimentation and mélange-forming processes in similar geotectonic settings as well as the appearance of submarine landslides along the subduction margin at the front of accretionary prisms were described by Alonso et al. (2006), Yamamoto et al. (2009), Yamada et al. (2010) and Festa et al. (2010, 2012, 2016), among others. Concurrent tectonic and gravitational motions leading to the formation of polygenetic olistostromes are common in a large part of the Western Alps at the top of the Alpine foreland basin succession (Perotti et al. 2012) and in the Northern Apennines (Pini 1999; Codegone et al. 2012; Ogata et al. 2012). Also the Miocene of the Outer Carpathians is full of chaotic sediments, the diachronous character of which has been underlined by Jankowski and Jarmołowicz-Szulc (2009).

Defining the Grajcarek Unit as a structural unit would require not only a coherent tectonosedimentary evolution 
and a precise timing of the deformation episodes but also a straightforward definition of its northern border. To date, this border is fuzzy and defined differently by different authors. The difficulty in locating the northern border of the "Grajcarek Unit" is due to the fact that folding, slicing and thrusting, as well as the emplacement range of olistoliths and thrust sheets/olistolith slumps, vanished gradually (and towards the north) both in time and space. It is difficult to decide if the northern limit of the "Grajcarek Unit" should be that of the northernmost olistolith, the occurrence of stronger folding or a particular thrust or fault. A similar problem arises with the southern boundary: in many cases we cannot be sure if it is a fragment of a tectonic unit belonging to the PKB thrust onto the Šariš Unit, or it is an olistolith within a chaotic mélange. As Plašienka (2011) stated: "the long-termed tectonic deformation processes were repeatedly accompanied by deposition of synorogenic and followed by overstepping formations (...) which were further deformed together with their substratum". However, there was no independent tectonic unit, neither during folding and thrusting in the PKB (Cretaceous/Paleogene), nor during folding in the Outer Carpathians (Miocene).

\section{Conclusions}

During the Early Jurassic-Early Cretaceous, the Grajcarek Basin (pre-Late Albian Magura Basin) was located north of the Czorsztyn Ridge (Oravicum), limiting the Pieniny-Subpieniny Basin (Birkenmajer 1986; Segit et al. 2015). This basin remained distinct until the Late Albian, i.e. until the disappearance of the Czorsztyn Ridge (e.g. Barski et al. 2012). This submerging resulted in deepening and uniform of facies within the Pieniny-Subpieniny, the Grajcarek and the Magura basins. From the Late Albian onward, the Grajcarek Basin was integrated into the Magura Basin and its further evolution was connected with the Outer Carpathians. During the Late Cretaceous/Paleocene thrust-folding processes, the Peri-Klippen zone of the Magura Basin was partially folded and reduced. In the Magurian front of the klippen belt polygenetic and polyphase tectono-sedimentary chaotic mélange did form, advancing towards the north with progressive evolution and subjecting progressively younger deposits to progressively younger deformation. These processes were accompanied by numerous olistolith-forming events, the latter sliding gravitationally from a growing accretionary prism. All these sediments were deformed once more due to Late Oligocene/Miocene folding and thrusting processes in the Outer Carpathians. In summary, the Šariš Transitional Zone formed all along the northern rim of the PKB, being composed of the result of multiple reworking of sediments that originated both in the Grajcarek Basin and in the Peri-Klippen part of the Magura Basin that contains numerous olistholiths of the PKB units.

The alteration of tectonic structures along strike in the $\mathrm{PKB}$ is due to variations within the basement (underplated North-European Platform), cut by several deep fracture zones, parallel to the Teisseyre-Tornquist Zone (NNW$\mathrm{SSE}$ ). The most important of these fracture zones is the prolongation of the limit of the Upper Silesian and Małopolska blocks (Kraków-Myszków Fault Zone; Buła and Żaba 2008) below the Carpathians. The surficial expression of this zone in the PKB is the Dunajec Fault and in the Magura Nappe the andesite dyke array which has an en échelon relationship to this fault (Jurewicz 2005; Nejbert et al. 2012). Along this deep fracture zone, the platform basement in its eastern side is downthrown in a stair-step fashion by ca. $3 \mathrm{~km}$ as compared to the western side of this fault (Zuchiewicz and Oszczypko 2008). Such a morphology of the basement influenced subduction and later collision of the European plate with the Central Carpathians Block.

Right-lateral movement along NNW-SSE oriented strike-slip faults within the PKB mentioned above was also responsible for the formation of strike-slip duplexes, with increasing (towards the east) amplitude of overthrusting of klippen units over the Magurian foreland and the arc-like horizontal plan of the klippen belt.

The presence of Eocene-Oligocene sediments in the Plaveč graben (Leško 1960; Nemcok 1990a, b; Plašienka and Mikuš 2010) as well as Lower Miocene andesite dykes (Birkenmajer and Pécskay 1999, 2000a) proves strike-slip motion along NNW-SSE faults in the Outer Carpathian basement. These faults subdivide the PKB into a series of segments, which preclude the possibility of late, i.e. Neogene, longitudinal movement along the northern boundary of the PKB and $\mathrm{CCW}$ rotation of the Central Carpathian Block. Such a rotation, related to Alcapa Block motion, took place earlier, that is from Albian to Paleocene, and was responsible for the formation of pull-apart basins, filled with Gosau facies (Wagreich and Marschalko 1995).

Acknowledgements This paper was financially supported by the University of Warsaw fund BST186/702. I am grateful to Dušan Plašienka and Anonymous Reviewers for the critical and constructive discussion of an earlier version of the manuscript. Special thanks are also due to Stefan Schmid whose constructive comments and suggestion greatly improved the text. I like to thank Ewa Szynkaruk for linguistic advice.

Open Access This article is distributed under the terms of the Creative Commons Attribution 4.0 International License (http://crea tivecommons.org/licenses/by/4.0/), which permits unrestricted use, distribution, and reproduction in any medium, provided you give appropriate credit to the original author(s) and the source, provide a link to the Creative Commons license, and indicate if changes were made. 


\section{References}

Alexandrowicz, S., \& Geroch, S. (1963). Assotiation de petit Foraminifers dans 1'Eocene de la Tatra. Annales Societatis Geologorum Poloniae, 33, 219-228.

Allerton, S. (1998). Geometry and kinematics of vertical-axis rotations in fold and thrust belts. Tectonophysics, 299, 15-30.

Alonso, J. L., Marcos, A., \& Suarez, A. (2006). Structure and organization of the Porma Mélange: progressive denudation of a submarine nappe toe by gravitational collapse. American Journal of Science, 306, 32-65.

Andrusov, D. (1938). Étude géologique de la zone des Klippes internes des Carpathes Occidentales, 3e partie: Tectonique. State Geological Survey, $135 \mathrm{pp}$, Prague.

Andrusov, D. (1968). Grundriss der Tectonik der nordlichen Karpaten, 188 pp. Vydavatel'stvo Slovenskej Academie Vied; Bratislava.

Andrusov, D. (1974). The Pieniny Klippen Belt (The Carpathians of Cechoslovakia). In: M. Mahel' (Ed.), Tectonics of the Carpathian-Balkan regions. 145-158. Bratislava.

Aubrecht, R., Krobicki, M., Sýkora, M., Mišik, M., Borová, D., Schlögl, J., et al. (2006). Early Cretaceous hiatus in the Czorsztyn Succession (Pieniny Klippen Belt), Western Carpathians): submarine erosion or emersion. Annales Societatis Geologorum Poloniae, 76, 161-196.

Aubrecht, R., Mišik, M. \& Sýkora, M. (1997). Jurassic synrift sedimentation on the Czorsztyn Swell of the Pieniny Klippen Belt in Western Slovakia. Alpine evolution of the Western Carpathians and related areas. Bratislava, Slovakia, September 11-14th 1997, 53-64.

Aubrecht, R., \& Túnyi, I. (2001). Original orientation of neptunian dykes in the Pieniny Klippen Belt (Western Carpahtians): the first results. Contributions to Geophysics and Geodesy, 31, 557-578.

Baková, L., \& Soták, J. (2000). Tectonosedimentary formation of the Pieniny Klippen Belt (Orava, Slovakia). Slovak Geological Magazine, 6, 302-303.

Barski, M., Matyja, B. A., Segit, T., \& Wierzbowski, A. (2012). Early to Late Bajocian age of the so called "black flysch" (Szlachtowa Formation) depos its: implications for the history and geological structure of the Pieniny Klippen Belt, Carpathians. Geological Quarterly, 56, 391-410.

Bieda, F. (1959). Nummulite fauna in the Tatra Eocene. Biuletyn Instytut Geologicznego, 141, 5-13.

Bieda, F. (1963). Larger foraminifers of the Tatra Eocene. Prace Instytutu Geologicznego, 37, 1-215.

Birkenmajer, K. (1959). Diapiric tectonics in the Pieniny Klippen Belt (Carpathians). Bulletin de l'Académie polonaise des sciences. Série des sciences chimiques, 7, 123-128.

Birkenmajer K. (1963). Stratigraphy and palaeogeography of the Czorsztyn series (Pieniny Klippen Belt, Carpathians) Poland. Studia Geologica Polonica, 9, 380 pp. (in Polish with English summary).

Birkenmajer K. (1970). Pre-Eocene fold structure fold structures in the Pieniny Klippen Belt (Carpathians) of Poland. Studia Geologica Polonica, 31, 77 pp. (in Polish with English summary).

Birkenmajer K. (1977). Jurassic and Cretaceous lithostratigraphic Units of the Pieniny Klippen Belt, Carpathians. Studia Geologica Polonica, 45, 158 pp. (in Polish).

Birkenmajer K. (1979). Pieniny Klippen Belt of Poland-geological guide. Wydawnictwa Geologiczne, Warszawa, 237 pp. (in Polish).

Birkenmajer, K. (1986). Stages of structural evolution of the Pieniny Klippen Belt, Carpathians. Studia Geologica Polonica, 88, 7-32.
Birkenmajer, K. (2001). Pieniny Klippen Belt. In: K. Birkenmajer, M. Krobicki (Eds), Carpathian Paleogeography and Geodynamics, a multidisciplinary approach. 12th Meeting Association of European Geological Societies, 10-15 September 2001 Kraków, Field trip gide, Polish Geological Institute, 9-141.

Birkenmajer, K., \& Dudziak, J. (1981). Age of the Magura flysch, Palaeogene, along the northern boundary of the Pieniny Klippen Belt, Carpathians, Poland, based on calcareous nannoplankton. Studia Geologica Polonica, 70, 7-36.

Birkenmajer, K., \& Dudziak, J. (1991). Middle to Late Palaeocene Nannoplankton Zones in the Jarmuta Formation, Pieniny Klippen Belt, Carpathians. Bulletin of the Polish Academy of Sciences, Earth Sciences, 39, 47-52.

Birkenmajer, K., Dudziak, J., \& Jednorowska, A. (1979). Subsurface geological structure of the Northern Boundary Fault Zone of the Pieniny Klippen Belt at Szczawnica, Carpathians. Studia Geologica Polonica, 61, 7-32. (in Polish with English abstract).

Birkenmajer, K., Gąsiorowski, M., \& Wieser, T. (1960). Fragments of exotic rocks in the pelagic deposits of the Bathonian of the Niedzica Series, Pieniny Klippen Belt, Carpathians. Annales de la Societe Geologique de Pologne, 30, 31-57.

Birkenmajer, K., \& Gedl, P. (2017). The Grajcarek Succession (Lower Jurassic-mid Paleocene) in the Pieniny Klippen Belt, West Carpathians, Poland: a stratigraphic synthesis. Annales Societatis Geologorum Poloniae, 87, 55-88.

Birkenmajer, K., Gedl, P., Myczynski, R., \& Tyszka, J. (2008). "Cretaceous black flysch" in the Pieniny Klippen Belt, West Carpathians: a case of geological misinterpretation. Cretaceous Resarche, 29, 535-549.

Birkenmajer, K., \& Pazdro, O. (1968). On the so-called "Sztolnia Beds" in the Pieniny Klippen Belt in Poland. Acta Geologica Polonica, 18, 325-363.

Birkenmajer, K., \& Pécskay, Z. (1999). K-Ar dating of the Miocene andesite intrusions, Pieniny Mts, West Carpathians. Bulletin of the Polish Academy of Sciences, Earth Sciences, 47, 155-169.

Birkenmajer, K., \& Pécskay, Z. (2000a). K-Ar dating of the Miocene andesite intrusions, Pieniny Mts, West Carpathians, Poland: a supplement. Studia Geologica Polonica, 117, 7-25.

Birkenmajer, K., \& Pécskay, Z. (2000b). Early Cretaceous K-Ar age of a large basalt olistolith at Biała Woda, Pieniny Klippen Belt, West Carpathians, Poland. Studia Geologica Polonica, 117, 27-35.

Buček, S. (2001). Borové Formation of the Eocene age east of the Tatra Mts. Slovak Geological Magazine, 7, 45-52.

Buła, Z., Jachowicz, M., \& Żaba, J. (1997). Principal characteristics of the Upper Silesian Block and Małopolska Block border zone, Southern Poland. Geological Magazine, 134, 669-677.

Buła, Z., \& Żaba, J. (2008). Structure of the Precambrian basement of the eastern part of the Upper Silesian block (Brunovistulicum). Przeglad Geologiczny, 56, 473-480. (in Polish).

Cieszkowski, M. (1992). Marine Miocene deposits near Nowy Targ, Magura nappe, Flysch Carpathians (south Poland). Geologica Carpathica, 43, 339-346.

Codegone, G., Festa, A., Dilek, Y., \& Pini, A. G. (2012). Small-scale polygenetic mélanges in the Ligurian accretionary complex, Northern Apennines, Italy, and the role of shale diapirism in superposed mélange evolution in orogenic belts. Tectonophysics, 568-569, 170-184.

Csontos, L., \& Vörös, A. (2004). Mesozoic plate tectonic reconstruction of the Carpathian region. Palaeogeography, Palaeoclimatology, Palaeoecology, 210, 1-56.

Dadlez, R. (2006). The Polish Basin-relationship between the crystalline, consolidated and sedimentary crust. Geological Quarterly, 50, 43-58. 
Doktór, S., Graniczny, M., Kowalski, Z., \& Wójcik, A. (2002). Application of radar images interpretation for tectonic analysis of the Carpathians. Przeglad Geologiczny, 50, 852-860.

Dumont, T., Wieczorek, J., \& Boullin, J. P. (1996). Inverted Mesozoic rift structures in the Polish Western Carpathians (High-Tatric units). Comparision with similar features in the Western Alps. Eclogae Geologicae Helvetiae, 89, 181-202.

Embey-Isztin, A., Downes, H., James, D. E., Upton, B. G. J., Dobosi, G., Ingram, G. A., et al. (1993). The petrogenesis of Pliocene alkaline volcanic rocks from Pannonian basin, eastern central Europe. Journal of Petrology, 34, 317-343.

Festa, A., Dilek, Y., Pini, G. A., Codegone, G., \& Ogata, K. (2012). Mechanisms and processes of stratal disruption and mixing in the development of mélanges and broken formations: Redefining and classifying mélanges. Tectonophysics, 568-569, 7-24.

Festa, A., Ogata, K., Dilek, K., Pini, G. A., \& Alonso, J. L. (2016). Origin and significace of olistostromes in the evolution of orogenic belts: A global synthesis. Gondwana Research, 39, 180-203.

Festa, A., Pini, G.A., Dilek, Y. \& Codegone, G. (2010). Mélanges and mélange-forming processes: a historical overview and new concepts. In: Y. Dilek (Ed.), Alpine concept in geology, International Geology Review, 52, 1040-1105.

Fodor, L. (1995). From transpression to transtension: OligoceneMiocene structural evolution of the Vienna Basin and the East Alpine-Western Carpathian junction. Tectonophysics, 242, 151-182.

Fodor, L. (2004). What are the tectonic units in the PannonianCarpathian-Eastern Alpine Domain: Terminological question or key to understand structural evolution? Geolines, 17, 32-33.

Froitzheim, N., Plašienka, D. \& Schuster, R. (2008). Alpine tectonics of the Alps and Western Carpathians. In: T. McCann (Ed.) The Geology of Central Europe, 2: Mesozoic and Cenozoic 1141-1232. Geological Society Publishing House; London.

Gągała, Ł., Vergés, J., Saura, E., Malata, T., Ringenbach, J. C., Werner, P., et al. (2012). Architecture and orogenic evolution of the northeastern Outer Carpathians from cross-section balancing and forward modeling. Tectonophysics, 532-535, 223-241.

Gawęda, A., Burda, J., Golonka, J., Klötzli, U., Chew, D., Szopa, K., et al. (2017). The evolution of Eastern Tornquist-Paleoasian Ocean and subsequent continental collisions: A case study from the Western Tatra Mountains, Central Western Carpathians (Poland). Gondwana Research, 48, 134-152.

Gedl, P. (1999). The age of base and top of the Podhale Palaeogene flysch (Central Carpathians, Poland), based on dinocysts. Bulletin of the Polish Academy of Sciences, Earth Sciences, 47, 77-102.

Gedl, P. (2000). Biostratigraphy and palaeoenvironment of the Podhale Palaeogene (Inner Carpathians, Poland) in the light of palynological studies. Part I-II. Studia Geologica Polonica, 117, 89-303.

Gedl, P. (2008). Organic-walled dinoflagellate cyst stratigraphy of dark Middle Jurassic marine deposits of the Pieniny Klippen Belt, West Carpathians. Studia Geologica Polonica, 131, 7-227.

Głazek, J. (2000). Pre-Eocene karst of the Tatra Mts. In Baryła J., Gradzinski M. \& Szelerewicz M. (Eds.) Proceedings of 34th Congress of Speleology, Koscielisko, 20-22.10.2000, 23-25. Sekcja Speleoologiczna Polskiego Towarzystwa Przyrodników im. Kopernika, Kraków (in Polish).

Głazek, J. \& Zastawniak, E. (1999). Terrestrial plant fossils in the transgressive Paleogene littoral/flysch sequence of the Tatra Mountains (Central Carpathians). Acta Palaeobotanica, Suppl. 2. Proceedings of the 5th EPPC, 293-301.

Gołąb, J. (1959). On the geology of the Western Podhale flysch area. Biuletyn Instytutu Geologicznego, 149, 225-240.
Golonka, J., \& Krobicki, M. (2001). Upwelling regime in the Carpathian Tethys: a Jurassic-Cretaceous palaeogeographic and paleoclimatic perspective. Geological Quarterly, 45, 15-32.

Golonka, J., \& Krobicki, M. (2004). Jurrasic Paleogeography of the Pieniny and Outer Carpathian Basins. Rivista Italiana di Paleontologia e Stratigrafia, 110, 5-14.

Golonka, J., Krobicki, M., Waśkowska, A., Cieszkowski, M., \& Ślaczka, A. (2015). Olistostromes of the Pieniny Klippen Belt, Northern Carpathians. Geological Magazine, 152, 269-286.

Golonka, J., Oszczypko, N., \& Slączka, A. (2000). Late Carboniferous-neogene geodynamic evolution and paleogeography of the circum Carpathian region and adjacent areas. Annales Societatis Geologorum Poloniae, 70, 107-136.

Golonka, J., \& Raczkowski, W. (1981). Detail Geological Map of Poland 1:50,000, Piwniczna sheet. Warszawa: Wydawnictwa Geologiczne. (in Polish).

Golonka, J. \& Rączkowski, W. (1984). Explanations to Detail Geological Map of Poland, Piwniczna sheet, Wydawnictwa Geologiczne, Warszawa, 85p. (in Polish).

Golonka, J., \& Waśkowska, A. (2014). Paleogene of the Magura Nappe adjacent to the Pieniny Klippen Belt between Szczawnica and Krościenko (Outer Carpathians, Poland). Geology, Gephysics and Environment, 40, 359-376.

Gross, P., Köhler, E. \& Samuel, O. (1984). Lithostratigraphic division of the Central-Carpathian Paleogene. Geologické Práce, Správy, 81, 103-117. (in Slovak, English summary).

Guterch, A., \& Grad, M. (2006). Lithospheric structure of the TESZ in Poland based on modern seismic experiments. Geological Quarterly, 50, 23-32.

Guterch, B., Lewandowska-Marciniak, H., \& Niewiadomski, J. (2005). Earthquakes recorded in Poland along the Pieniny Klippen Belt. Western Carpathians, Acta Geophysica Polonica, $53,27-45$.

Hofer, G., Wagreich, M., \& Neuhuber, S. (2013). Geochemistry of fine-grained sediments of the Upper Cretaceous to Paleogene Gosau Group (Austria, Slovakia): Implications for paleoenvironmental and provenance studies. Geoscience Frontiers, 4, $449-468$.

Horwitz, L. (1935). Nouvelle coupe schématique de la Zone Piénine des Klippes (Karpates Polonaises). Sprawozdania Państwowego Instytutu Geologicznego, 8, 79-133. (in Polish, French summary).

Hrubcová, P., \& Środa, P. (2015). Complex local Moho topography in the Western Carpathians: Indication of the Alcapa and the European Plate contact. Tectonophysics, 638, 63-81.

Hrušecký, I., Pospišil, L., \& Kohút, M. (2002). Geological interpretation of the reflection seismic profile 753/92. In I. Hrušecký (Ed.), Hydrocarbon potential of the Eastern Slovakian Basin and Adjacent Areas. Bratislava: GSSR.

Hsü, K. J. (1968). Principles of mélanges and their bearing on the Franciscan Knoxville Paradox. Geological Society of America Bulletin, 79, 1063-1074.

Jacko, S., \& Janočko, J. (2000). Kinematic evolution of the CentralCarpathian Paleogene Basin in the Spišská Magura region (Slovakia). Slovak Geological Magazine, 6, 40-418.

Jankowski, L., \& Jarmołowicz-Szulc, K. (2009). Particular tectonic zones (the mélange zones) as potential and significant paths for fluid migration and mineral formation. Mineralogical Review, 59, 31-44.

Janočko, J., Gross, P., Buček, S., Karoli, S., Žec, B., Rakús, M., et al. (2000). Geological map of the Spišská Magura region 1:50,000. Bratislava: ŠGÚDŠ.

Janočko, J., \& Jacko, S. (1999). Marginal and deep-sea deposits of Central Carpathians Palaeogene Basin, Spišská Magura region, Slovakia: implication for basin history. Slovak Geological Magazine, 4, 281-292. 
Jarosiński, M. (1998). Contemporary stress field distortion in the Polish part of the Western Outer Carpathians and their basement. Tectonophysics, 297, 91-119.

Jarosiński, M. (2005). Ongoing tectonic reactivation of the Outer Carpathians and its impact on the foreland: Results of borehole breakout measurements in Poland. Tectonophysics, 410, 189-216.

Jurewicz, E. (1994). Structural analysis of the Pieniny Klippen Belt at Jaworki, Carpathians, Poland. Studia Geologica Polonica, 106, 7-87.

Jurewicz, E. (1997). The contact between the Pieniny Klippen Belt and Magura Unit (the Małe Pieniny Mts.). Geological Quarterly, 41, 315-326.

Jurewicz, E. (2005). Geodynamic evolution of the Tatra Mts. and the Pieniny Klippen Belt (Western Carpathians): problems and comments. Acta Geologica Polonica, 55, 295-338.

Jurewicz, E., Hercman, H., \& Nejbert, K. (2007). Flowstone-like calcite in the andesite of Jarmuta Mt.-dating the Holocene tectonic activity in the vicinity of Szczawnica Magura Nappe, Outer Carpathians, Poland. Acta Geologica Polonica, 57, 187-204.

Kazmer, M., Dunkl, I., Frisch, W., Kuhlemann, J., \& Ozsvart, P. (2003). The Palaeogene forearc basin of the Eastern Alps and Western Carpathians: subduction erosion and basin evolution. Journal of the Geological Society, 160, 413-428.

Köhler, E., Salaj, J., \& Bucek, S. (1993). Paleogeographical development of the Myjava sedimentary area (western Slovakia) during the existance of the Paleocene reef complex. Geologica Carpathica, 44, 373-380.

Kostka, A. (1993). The age and micro fauna of the Maruszyna Succession (Upper Cretaceous-Palaeogene), Pieniny Klippen Belt, Carpathians, Poland. Studia Geologica Polonica, 102, 7-134.

Kováč, M., Bielík, M., Hók, J., Kováč, P., Kronome, B., Labák, P., et al. (2002). Seismic activity and neotectonic evolution of the Western Carpathians (Slovakia). EGU Stephan Mueller Special Publication Series, 3, 167-184.

Kováč, P., \& Hók, J. (1996). Tertiary development of western part of Klippen Belt. Slovak Geological Magazine, 2, 137-149.

Kováč, M., \& Márton, E. (1998). To rotate or to not rotate: Palinspastic reconstruction of the Carpatho-Pannonian area during the Miocene. Slovak Geological Magazine, 4, 75-85.

Kozur, H., \& Mock, R. (1996). New paleogeographic and tectonic interpretations in Slovakian Carpathians and their implications for correlations with Eastern Alps. Part I: Central Western Carpathians. Mineralia Slovaca, 28, 151-174.

Książkiewicz, M. (1977). The tectonics of the Carpathians. In W. Pożaryski (Ed.), Geology of Poland Volume 4. Tectonics (pp. 476-699). Warszawa: Wydawnictwa Geologiczne.

Książkiewicz, M., \& Leško, B. (1959). On the correlation between the Krosno and Magura Flysch. Bulletin de l'Academie Polonaise des Sciences Géologiques et Géographiques, 7, 773-780.

Kutyba, J. (1986). Grajcarek Valley: Jarmuta Formation of the Grajcarek. In: K. Birkenmajer \& D. Poprawa (Eds), Przewodnik 57 Zjazdu PTG Pieniny 1986; 149-152. Zakład Graficzny AGH, Kraków 1986. (in Polish).

Leško, B. (1960). Palaogen der Klippenzone in der Ost slowakei. Geologický Sborník, 11, 95-103. (in Slovak).

Leško, B., Durkovič, T., Gašparíková, V., Samuel, O., \& Snopková, P. (1984). A geological evaluation of Hanušovce-1 borehole. Mineralia Slovaca, 16, 217-255. (in Slovak).

Leśniak, P., Sakai, H., Ishibashi, J., \& Wakita, H. (1997). Mantlehelium signal in the West Carpathians, Poland. Geochemical Journal, 31, 383-394.

Łój, M., Madej, J., Porzucek, S., \& Zuchiewicz, W. (2009). Monitoring geodynamic processes using geodetic and gravimetric methods: an example from the Western Carpathians (South Poland). Geologia, 35, 217-247.

Mahel', M. (1980). The Peri-klippen zone: its nearer characterization and significance. Mineralia Slovaca, 12, 193-207. Bratislava.

Mahel', M. (1989). The Klippen Belt from the aspect of geodynamic model. Mineralia Slovaca, 21, 99-108. (in Slovak).

Marchant, R. H., \& Stampfli, G. M. (1997). Subduction zone in the Western Alps. Tectonophysics, 269, 217-235.

Marschalko, R. (1968). Facies, distribution, paleocurrents and paleotectonics of the Paleogene flysch of Central West Carpathians. Geologický Zborník-Geologica Carpathica, 19, 69-94.

Márton, E., Grabowski, J., Plašienka, D., Túnyi, I., Krobicki, M., Haas, J., et al. (2013). New paleomagnetic results from the Upper Cretaceous red marls of the Pieniny Klippen Belt, Western Carpathians: Evidence for general $\mathrm{CCW}$ rotation and implications for the origin of the structural arc formation. Tectonophysics, 592, 1-13.

Márton, E., Mastella, L., \& Tokarski, A. K. (1999). Large counterclockwise rotation of the Inner West Carpathian Paleogene Flysch-evidence from paleomagnetic investigation of the Podhale Flysch (Poland). Physics and Chemistry of the Earth, 24, 645-649.

Márton, E., Tokarski, A. K., \& Halász, D. (2004). Late Miocene counter-clockwise rotation of the Pieniny andesites at the contact of the Inner and Outer Carpathians. Geologica Carpathica, 55, 411-419.

Mastella, L. (1975). Flysch tectonic in the eastern part of the Podhale Basin (Carpathians, Poland). Annales Societatis Geologorum Poloniae, 45, 361-401. (in Polish).

Mazur, S., Mikolajczak, M., Krzywiec, P., Malinowski, M., Buffenmyer, V., \& Lewandowski, M. (2015). Is the TeisseyreTornquist Zone an ancient plate boundary of Baltica? Tectonics, $34,2465-2477$.

Morgiel, J. \& Sikora, W. (1975). Upper Cretaceous and Palaeogene of Zlatne Unit in the Pieniny Klippen Belt. In: Proceedings of the Xth Congress of the Carpathian-Balkan Geological Association, Tectonics, section III: 254-261. Geologický Ústav D. Štúra, Bratislava (in Russian).

Nejbert, K., Jurewicz, E., \& Macdonald, R. (2012). Potassium-rich rocks in the Western Outer Carpathians: magmagenesis in transitional zone between European Plate and the CarpathianPannonian regions. Lithos, 146-147, 34-47.

Nemčok, J. (1990a). Geological Map of Pieniny, Lubovnianska Vrchovina Highland and Čergov Mts. Bratislava: Geologicky Ustav D. Štura.

Nemčok, J. (1990b). Explanations to the Geological Map of Pieniny, Lubovnianska Vrchovina Highland and Čergov Mts (p. 131p). Bratislava: Geologicky Ustav D. Štura.

Nemčok, J., Kullmanová, A., \& Durkovič, T. (1989). Development and stratigraphic position of the Gregorianka breccias of the Klippen Belt in eastern Slovakia. Geologické Práce, Správy, 89, 11-37. (in Slovak with English summary).

Nemčok, M., \& Nemčok, J. (1994). Late Cretaceous deformation of the Pieniny Klippen Belt, West Carpathians. Tectonophysics, 290, 137-167.

Nemčok, M., Pospišil, L., Lexa, J., \& Donelick, R. A. (1998). Tertiary subduction and slab break-off model of the Carpathian-Pannonian region. Tectonophysics, 295, 307-340.

Ogata, K., Mutti, E., Pini, G. A., \& Tinterri, R. (2012). Mass transport-related stratal disruption within sedimentary mélanges: Examples from the northern Apennines (Italy) and south-central Pyrenees (Spain). Tectonophysics, 568-569, 185-199.

Olszewska, B., \& Wieczorek, J. (1998). The Paleogene of the Podhale Basin (Polish Central Carpathians)-micropaleontological perspective. Przeglad Geologiczny, 46, 721-728. 
Oszczypko, N. (1998). The Western Carpathian Foredeep-development of the foreland basin in front of the accretionary wedge and its burial history (Poland). Geologica Carpathica, 49, 415-431.

Oszczypko, N. (2006). Late Jurassic-Miocene evolution of the Outer Carpathian fold-and thrust belt and its foredeep basin (Western Carpathians, Poland). Geological Quarterly, 50, 169-194.

Oszczypko, N., Andreyeva-Grigorovich, A. S., Malata, E., \& Oszczypko-Clowes, M. (1999). The Lower Miocene deposits of the Rača Sub-Unit near Nowy Sącz (Magura Nappe, Polish Outer Carpathians). Geologica Carpathica, 50, 419-433.

Oszczypko, N., Jurewicz, E. \& Plašienka, D. (2010). Tectonics of the Klippen Belt and Magura Nappe in the Eastern Part of the Pieniny Mts. (Western Carpathians, Poland and Slovakia)-new approches and results. In Christofides G., Kantiranis N., Kostopoulos D.S. \& Chatzipetros A. (Eds.), Proceedings XIX Congress of the Carpathian-Balkan Geological Association, Thessaloniki, Greece, 23-26 September 2010, Scientific Annales of the School of Geology, Aristotle University of Thessaloniki, Faculty of Sciences, Special Volume 100, 1-2, 221-230.

Oszczypko, N., Olszewska, B., \& Malata, E. (2012). Cretaceous (Aptian/Albian-?Cenomanian) age of "black flysch" and adjacent deposits of the Grajcarek thrust-sheets in the Małe Pieniny Mts. (Pieniny Klippen Belt, Polish Outer Carpathians). Geological Quarterly, 56, 411-440. https://doi.org/10.7306/gq.1031.

Oszczypko, N., \& Oszczypko-Clowes, M. (2002). Newly discovered Early Miocene deposits in the Nowy Sacz area (Magura Nappe, Polish Outer Carpathians). Geological Quarterly, 46, 15-30.

Oszczypko, N., \& Oszczypko-Clowes, M. (2003). The Aquitanian marine deposits in the basement of PolishWestern Carpathians and its palaeogeographical and palaeotectonic implications. Acta Geologica Polonica, 53, 101-122.

Oszczypko, N., \& Oszczypko-Clowes, M. (2010). The Paleogene and Early Nogene stratigraphy of the Beskid Sadecki Range and Lubovnianska Vrchovina (Magura Nappe, Western Carpathians). Acta Geologica Polonica, 60, 317-348.

Oszczypko, N., \& Oszczypko-Clowes, M. (2014). Geological structure and evolution of the Pieniny Klippen Belt to the east of the Dunajec River-a new approach (Outer Western Carpathians, Poland). Geological Quarterly, 58, 737-758. https://doi.org/10. 7306/gq.1177.

Oszczypko, N., Oszczypko-Clowes, M., Golonka, J., \& Marko, F. (2005). Oligocene-Lower Miocene sequences of the Pieniny Klippen Belt and adjacent Magura Nappe between Jarabina and the Poprad River (East Slovakia and South Poland)-their tectonic position and paleogeographic implications. Geological Quarterly, 49, 379-402.

Oszczypko, N., Ślączka, A., Oszczypko-Clowes, A., \& Olszewska, B. (2015). Where was the Magura Ocean. Acta Geologica Polonica, 65, 319-344. https://doi.org/10.1515/agp-2015-0014

Perotti, E., Bertok, C., d'Atri, A., Martire, L., Piana, F., \& Catanzariti, R. (2012). A tectonically-induced Eocene sedimentary mélange in the West Ligurian Alps, Italy. Tectonophysics, 568-569, 200-214.

Pharaoh, T. C. (1999). Palaeozoic terranes and their lithospheric boundaries within the Trans-European Suture Zone (TESZ): a review. Tectonophysics, 314, 17-41.

Pini, G. A. (1999). Tectonosomes and olistostromes in the Argile Scagliose of the Northern Apennines, Italy. Geological Society of America Special Paper, 335, 73 pp.

Piotrowski, J. (1978). Mesostructural analysis of the main tectonic units of the Tatra Mts. Studia Geologica Polonica, 55, 1-80. (in Polish).

Plašienka, D. (1996). Mid-Cretaceous (120-80 Ma) orogenic processe in the Central Western Carpathians: brief review and interpretation of data. Slovak Geological Magazine, 3-4, 319-324.
Plašienka, D. (1999). Tectonochronology and paleotectonic evolution of the Central Western Carpathians during the Jurassic and Cretaceous. 127 pp. Veda; Bratislava. (in Slovak).

Plašienka, D. (2002). Origin and growth of the West Carpathian orogenic edge during the Mesozoic. Geologica Carpathica, 94, 132-135.

Plašienka, D. (2003). Dynamics of Mesozoic pre-orogenic rifting in the Western Carpathians. Austrian Journal of Earth Sciences, 94 , 79-98.

Plašienka, D. (2011). The Pieniny Klipp en Belt-structure, evolution and position in the Carpathian tectonic framework. Geologické Výzkumy na Moravě a ve Slezsku, 39-44.

Plašienka, D. (2012a). Early stages of structural evolution of the Carpathian Klippen Belt (Slovakian Pieniny sector). Mineralia Slovaca, 44, 1-16.

Plašienka, D. (2012b). Jurassic syn-rift and Cretaceous synorogenic, coarse-grained deposits related to opening and closure of the Vahic (South Penninic) Ocean in the Western Carpathians-an overview. Geological Quarterly, 56, 601-628.

Plašienka, D., Grecula, P., Putiš, M., Kováč, M. \& Hovorka, D. (1997). Evolution and structure of the Western Carpathians: an overview. Mineralia Slovaca, In: Grecula P., Putiš \& Hovorka D. (Eds), Geological evolution of the Western Carpathians: $1-24$.

Plašienka, D., Michalĺk, J., Gross, P., \& Putiš, M. (1991). Paleotectonic evolution of the Malé Karpaty Mts.-an overview. Geologica Carpathica, 42, 195-208.

Plašienka, D., \& Mikuš, V. (2010). Geologická stavba pieninského a šariškého úseku bradlového pásma medzi Litmanovou a Drienicou na východnom Slovensku. Mineralia Slovaca, 42, 155-178. (in Slovak).

Plašienka, D., \& Soták, J. (2015). Evolution of Late CretaceousPalaeogene synorogenic basins in the Pieniny Klippen Belt and adjacent zones (Western Carpathians, Slovakia): tectonic controls over a growing orogenic wedge. Annales Societatis Geologorum Poloniae, 85, 43-76.

Plašienka, D., Soták, J., Aubrecht, R., \& Michalík, J. (2016). Discussion of 'Olistostromes of the Pieniny Klippen Belt Northern Carpathians. Geological Magazine. https://doi.org/10. 1017/s0016756815000813.

Plašienka, D., Soták, J., Jamrichová, M., Halásová, E., Pivko, D., Józsa, S., et al. (2012). Structure and evolution of the Pieniny Klippen Belt demonstrated along a section between Jarabina and Litmanová villages in the Eastern Slovakia. Mineralia Slovaca, 44, 17-38.

Potfaj, M. (1997). Relation of the Klippen Belt and the Flysch zone in the territory of western Slovakia. Alpine evolution of the Western Carpathians and related areas (pp. 119-126). Bratislava: Dionýz Štúr Publishers.

Pożaryski, W. (1991). The strike-slip terrane model for the North German-Polish Caledonides. Publications of the Institute of Geophysics, Polish Academy of Sciences, A-19, 236, 3-15.

Rakús, M., \& Marschalko, R. (1997). Position of the Manin, Drietoma and Klape units at the boundary of the Central and Outer Carpathians. Alpine evolution of the Western Carpathians and related areas (pp. 79-97). Bratislava: Dionýz Štúr Publishers.

Ratschbacher, L., Frisch, W., Linzer, H. G., Sperner, B., Meschede, M., Decker, K., et al. (1993). The Pieniny Klippen Belt in the Western Carpathians of northeastern Slovakia: structural evidence for transpression. Tectonophysics, 226, 471-483.

Royden, L. H. (1993). The tectonic expression slab pull at continental convergent boundaries. Tectonics, 12, 303-325.

Scheck, M., Bayer, U., Otto, V., Lamarche, J., Banka, D., \& Pharaoh, T. (2002). The Elbe Fault System in North Central Europe-a basement controlled zone of crustal weakness. Tectonophysics, $360,281-299$. 
Scheibner, E. (1968). Contribution to the Knowledge of the Paleogene Reef-Complexes of the Myjava-Hričov-Haligovka Zone (West Carpathians). Mitteilungen Der Bayerischen Staatssammlung Fuer Palaeontologie Und Historische Geologie, 8, 67-97.

Schlögl, J., Plašienka, D., Aubrecht, R., Michalík, J., Sýkora, M. \& Potfaj, M. (2008). Composition, structure and evolution of the Pieniny Klippen Belt and adjacent zones in western Slovakia, Excursion Guide. In: Németh, Z. Plašienka, D. (Eds) SlovTec 08, Proceedings and Excursion Guide, 203-235, State Geological Institute of D. Stur. Bratislava.

Schmid, S. M., Bernoulli, D., Fügenschuh, B., Matenco, L., Schefer, S., Schuster, R., et al. (2008). The Alpine-Carpathian-Dinaridic orogenic system: correlation and evolution of tectonic units. Swiss Journal of Geosciences, 101, 139-183.

Segit, T., Matyja, B. A., \& Wierzbowski, A. (2015). The Middle Jurassic succession in the central sector of the Pieniny Klippen Belt (Sprzycne Creek); implication for the timing of the Czorsztyn Ridge development. Geologica Carpathica, 66, 285-302.

Sikora, W. (1962). New data on the geology of the Pieniny Klippen Belt. Bulletin de l'Académie Polonaise des Sciences, Série des Sciences Géologiques et Géographiques, 10, 203-211.

Sikora, W. (1970). On the Eocene transgression in the Pieniny Klippen Belt. Geological Quarterly, 14, 165-181. (in Polish).

Sikora, W. (1971). Esquisse de la tectogénèse de la zone des Klippes des Pieniny en Pologne d'après de nouvelles données géolgiques. Rocznik Polskiego Towarzystwa Geologicznego, 4, 221-239.

Soták, J., Pereszlényi, M., Marschalko, R., Milička, J., \& Starek, D. (2001). Sedimentology and hydrocarbon habitat of the submarine-fan deposits of the Central Carpathian Paleogene Basin (NE Slovakia). Marine and Petroleum Geology, 18, 87-114.

Sperner, B., Ratsbacher, L., \& Němcok, M. (2002). Interplay between subduction retreat and lateral extrusion: Tectonics of the Western Carpathians. Tectonics, 21, 1051-1075.

Srnanek, J., \& Salaj, J. (1965). Remarks to the geology of the Pieniny part of Klippen belt in the vider vicinity of Stará Lubovňa. Geologicke Prace, Bratislava, 35, 61-72.

Środoń, J., Kotarba, M., Biroň, A., Such, P., Clauer, R. \& Wójtowicz, A. (2006). Diagenetic history of the Podhale-Orava Basin and the underlying Tatra sedimentary structural units (Western Carpathians): evidence from XRD and $\mathrm{K}-\mathrm{Ar}$ of illite-smectite. https://doi.org/10.1180/0009855064130217.

Stampfli, G. M. (1993). Le Briançonnais, terrain exotique dans les Alpes? Eclogae Geologicae Helvetiae, 86, 1-45.

Stampfli, G. M., Mosar, J., Marquer, D., Marchant, R., Baudin, T., \& Borel, G. (1998). Subduction and obduction processes in the Swiss Alps. Tectonophysics, 296, 159-204.

Storey, M., Duncan, R. A., \& Swisher, C. C. (2007). Paleoceneeocene thermal maximum and the opening of the Northeast Atlantic. Science, 316(5824), 587-589. https://doi.org/10.1126/ science. 1135274 .

Świdrowska, J. \& Hakenberg, M. (2000). Palaeotectonic conditions of Cretaceous basin development in the southeastern segment of the Mid-Polish Trough. In: Crasquin-Soleau S. \& Barrier É. (Eds.), Memoires du Museum National d'Histoire Naturelle, 182, 239-256.

Tari, G., Báldi, T., \& Báldi-Beke, M. (1993). Paleogene retroarc flexural basin beneath the Neogene Pannonian Basin: a geodynamic model. Tectonophysics, 226, 455.

Tomek, Č. (1993). Deep crustal structure beneath the Central and Inner West Carpathians. Tectonophysics, 226, 417-431.

Tomek, Č., \& Hall, J. (1993). Subducted continental margin imaged in the Carpathians of Czechoslovakia. Geology, 21, 535-538.
Trümpy, R. (1988). Cent ans de la tectonique de nappes dans les Alpes. Compte Rendu de l'Académie des Sciences, Section, 2(302), 1-13.

Uchman, A., Rodríguez-Tovar, F. J., \& Oszczypko, N. (2013). Exceptionally favourable life conditions for macrobenthos during the late Cenomanian OAE-2 Event: ichnological record from the Bonarelli Level in the Grajcarek Unit, Polish Carpathians. Cretaceous Research, 46, 1-10.

Uhlig, V. (1899). Die Geologie des Tatragebirges. Theil II-IV. Denkschriften Mathematisch-Naturwissenschafthichen Classe. Academie der Wissenschaften. Wien. Bande, 68, 43-140.

Uhlig, V. (1905). Szczawnica sheet, scale 1:75,000. Wien: Geologische Specialkarte Österreich-Ungarischen Monarchie.

Uhlig, V. 1907. Über die Tektonik der Karpathen. Akademie der Wissenschaften, matematisch-naturwissenschaftliche Klasse, 116, part I, 871-982. Wien.

Wagreich, M., \& Marschalko, R. (1995). Late Cretaceous to Early Tertiary palaeogeography of the Western Carpathians (Slovakia) and the Eastern Alps (Austria): Implications from heavy mineral data. Geologische Rundschau, 84, 187-199.

Weissert, H., \& Bernoulli, D. (1985). A transform margin in the Mesozoic Tethys: evidence from the Swiss Alps. Geologische Rundschau, 74, 665-679.

Wiejacz, P. (1994). An attempt to determine tectonic stress patterns in Poland. Acta Geophysica Polonica, 3, 169-176.

Wierzbowski, A. (1994). Late Middle Jurassic to earliest Cretaceous stratigraphy and microfacies of the Czorsztyn Succesion in the Spisz area, Pieniny Klippen Belt, Poland. Acta Geologica Polonica, 44, 223-249.

Wierzbowski, A., Jaworska, M., \& Krobicki, M. (1999). Jurassic (upper Bajocian-lowest Oxfordian) ammonitico rosso facies in the Pieniny Klippen Belt, Carpathians, Poland: its, fauna, age, microfacies and sedimentary environment. Studia Geologica Polonica, 115, 7-74.

Yamada, Y., Yamashita, Y., \& Yamamoto, Y. (2010). Submarine landslides at subduction margins: Insights from physical models. Tectonophysics, 484, 156-167. https://doi.org/10.1016/j.tecto. 2009.09.007.

Yamamoto, Y., Nidaira, M., Ohta, Y., \& Ogawa, Y. (2009). Formation of chaotic rock units during primary accretion processes: examples from the Miura-Boso accretionary complex, central Japan. The Island Arc. https://doi.org/10.1111/j.14401738.2009.00676

Żaba, J. (1996). Late Carboniferous strike-slip activity at the boundary zone of Upper Silesia and Małopolska Blocks. Przeglad Geologiczny, 44, 173-180. (in Polish).

Zeyen, H., Dererova, J., \& Bielík, M. (2002). Determination of the continental lithospheric thermal structure in the Western Carpathians: integrated modelling of surface heat flow, gravity anomalies and topography. Physics of the Earth and Planetary Interiors, 134, 89-104.

Zoetemeijer, R., Tomek, C., \& Cloetingh, S. A. P. L. (1999). Flexural expression of European continental lithosphere under the Western Outer Carpathians. Tectonics, 18, 843-861.

Zuchiewicz, W. (2009). Neotectonics of the Polish Carpathians in the light of geomorphic studies: A state of the art. Acta Geodynamica et Geomaterialia, 6, 291-308.

Zuchiewicz, W., \& Oszczypko, N. (2008). Topography of the Magura floor thrust and morphotectonics of the Outer West Carpathians in Poland. Annales Societatis Geologorum Poloniae, 78, 135-148. 